\author{
МИНИСТЕРСТВО НАУКИ И ВЫСШЕГО ОБРАЗОВАНИЯ \\ РОССИЙСКОЙ ФЕДЕРАЦИИ \\ ФЕДЕРАЛЬНОЕ ГОСУДАРСТВЕННОЕ БЮДЖЕТНОЕ ОБРАЗОВАТЕЛЬНОЕ \\ УЧРЕЖДЕНИЕ ВЫСШЕГО ОБРАЗОВАНИЯ \\ «ВОРОНЕЖСКИЙ ГОСУДАРСТВЕННЫЙ ЛЕСОТЕХНИЧЕСКИЙ \\ УНИВЕРСИТЕТ ИМЕНИ Г.Ф. МОРОЗОВА»
}

\author{
ЦИФРОВОЕ ОБЩЕСТВО: \\ ПРОБЛЕМЫ И ПЕРСПЕКТИВЫ РАЗВИТИЯ
}

Сборник научных трудов по материалам

Всероссийской научно-практической конференции

22 апреля 2021 года

Воронеж 2021 
Ц75 Цифровое общество: проблемы и перспективы развития : сборник научных трудов по материалам Всероссийской научно-практической конференции 22 апреля 2021 года / под ред. д-ра ист. наук, доц. О. Н. Квасова ; М-во науки и высшего образования РФ, ФГБОУ ВО «ВГЛТУ». - Воронеж, 2021. -98 c.

ISBN 978-5-7994-0942-5 (в обл.)

Настоящий сборник составлен по материалам Всероссийской научно-практической конференции «Цифровое общество: проблемы и перспективы развития», прошедшей в ВГЛТУ 22 апреля 2021 года. Тематика конференции включает обширные проблемы цифровизации. Помимо социальных, экономических, политических и прочих перспектив, проникновение Цифры в культурное, образовательное и коммуникативное пространство вызывает неоднозначные, а подчас тревожные ожидания и последствия. Участники конференции на основе учебно-образовательных и воспитательных практик постарались приблизиться к пониманию противоречивости цифровизации общества, выработать современные методики учебного процесса, способствовать гуманизации учебновоспитательного пространства.

Сборник ориентирован на широкий круг читателей - практикующих специалистов, учёных, студентов, обществоведов и педагогов.

УДК 004:316

ББК 60.5 


\section{СОДЕРЖАНИЕ}

Сухоруких А.В. Методические аспекты преподавания дисциплины «Философия» в рамках дистанционного обучения в высшей школе 4

Белянская Т.Э. Цифровое пространство, как средство коммуникации студентов 10

Алесин И.И. Тенденции к симулякризации образовательной среды 15

Гришин А.А. Информационное проектирование учебной деятельности обучающихся в онтологиях волевого усилия и интертеймента

Моисеева М.П. Исследование психологического благополучия студентовпсихологов в условиях дистанционного обучения

Новикова 3.Н. Психологические особенности восприятия информации

в режиме онлайн

Петряева Т.А. Роль биографического метода в преодолении негативных последствий социализации подростков в пространстве цифрового общества... 39 Пушкина Т.Ф., Пушкин А.С. Риски цифровизации образования школьников подросткового возраста

Семенова Е.В. Трансформации коммуникативных процессов в цифровую эпоху 54

Трегубова А.С. Кибербуллинг в подростковой среде. 60

Чаплыгин А.В., Попова М.А. Цифровое общество как результат развития информационных технологий: к истории вопроса

Чучупал В.В. Цифровизация гуманитарных дисциплин в техническом вузе:

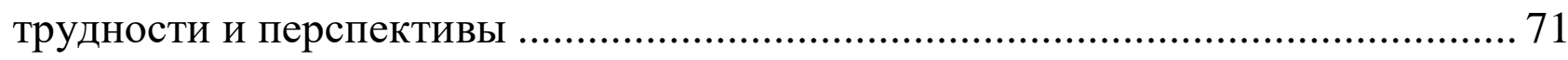

Щербинина О.С. Педагогическое общение в условиях цифровизации ............... 78 Комаров А.В. Опыт дистанционного обучения актёрскому мастерству во время карантина на примере объединения театр-студия «ГлаголЬ» ............. 84 Квасов О.Н. Институционализация киберпространства .................................... 89

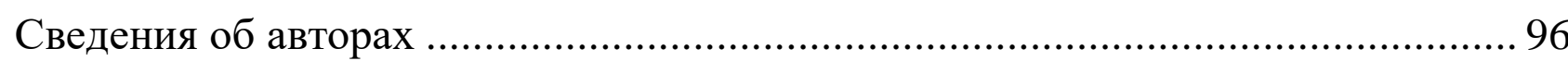


DOI

УДК 37.091.3

Сухоруких Алексей Викторович, доктор философских наук, доцент, Воронежский государственный лесотехнический университет имени Г.Ф. Морозова

\author{
МЕТОДИЧЕСКИЕ АСПЕКТЫ ПРЕПОДАВАНИЯ ДИСЦИПЛИНЫ \\ «ФИЛОСОФИЯ» В РАМКАХ ДИСТАНЦИОННОГО ОБУЧЕНИЯ \\ В ВЫСШЕЙ ШКОЛЕ
}

\title{
METHODOLOGICAL ASPECTS OF TEACHING THE DISCIPLINE «PHILOSOPHY» IN THE FRAMEWORK OF DISTANCE LEARNING IN HIGHER EDUCATION
}

\begin{abstract}
Аннотация: в работе анализируются методические аспекты преподавания дисциплины «Философия» в высшей школе в ситуации дистанционного образования и акцентируется внимание на необходимости сохранения целостного гносеологического антропософского дискурса и многоаспектного, системообразующего знания в «цифровом» формате обучения.
\end{abstract}

Abstract: The paper analyzes the methodological aspects of teaching the discipline «Philosophy» in higher education in the situation of distance education and focuses on the need to preserve the holistic epistemological anthroposophical discourse and multidimensional, systemforming knowledge in the «digital» learning format.

Ключевые слова: дистанционное образование, философия, учебный процесс, социализация

Key words: distance learning, philosophy, educational process, socialization

В условиях проектного введения дистанционного (смешанного) учебного процесса в высшей школе задача систематизации и качественного усвоения получаемого знания, его фундаментальность и глубина, остаётся приоритетным и чрезвычайно важным фактором обучения. Без его учёта теряет значение просветительский залог образовательной традиции, видятся несостоятельными принципы формирования человека как личностного и социального субъекта, как мыслителя и созидателя, сущностная духовно-нравственная монада 
которого несводима к рациональному функционированию нормативного конвейера обучения в сиюминутной социальной конъюнктуре [1]. Сегодняшняя презентационная апологетика неоправданно трудоёмкого и по факту ещё несовершенного «цифрового» контура не может отвлечь внимание педагогического сообщества от фактической дезорганизации реального учебного процесса и снижения качества получаемых знаний в российском образовательном пространстве [2]. Тогда как формирование многогранной человеческой личности, детерминированное имманентным нравственным фактором, фактически исключено из приоритетов просветительской повестки.

Целостный антропологический дискурс особенно значим для гуманитарных дисциплин, развивающих креативные и коммуникативные аспекты социализации учащихся, для дисциплины «Философия», в частности. Эта дисциплина остается эталоном гуманитарного знания в академическом курсе высшей школы, характеризующим, в первую очередь, фундаментальный статус учебного заведения. Неформальное преподавание дисциплины «Философия» в мировых образовательных системах носит элитарный статус. Она в значительной степени продолжает являться самым масштабной гносеологической константой современной образовательной среды, задающей импульс развития интегративному и этическому детерминированию знания, фундаментальные критерии которого остаются вехой соответствия любого инновационного ресурса предельным онтологическим коррелятам человеческой личности, социума, уровню культуры и просвещённости в нём.

В этой связи подчеркнём, что при дистанционном (смешанном) обучении спектр компетенций и навыков никак не должен быть ограничен заданным информационным ресурсом, он должен трансформироваться в способность самостоятельного мышления и реализации многомерных когнитивных смыслов, поиска ответов не только на утилитарно-практические задачи, но и на вызовы растущей экспоненты творческих замыслов человека, выводить гностику на онтологический план, актуализированный сегодня самой ситуацией времени.

С методической точки зрения принципиально отметить, что глобальный информационный ресурс должен видится педагогом только объективным инструментарием формирования учащимися их самостоятельной рефлексии, приобретения ими определённого ценностного опыта, того или иного 
сущностного смысла, а также этически обозначенного, субъективно-целостного многоаспектного знания.

Эрудиция и широта кругозора познания личности не должны подменяться легкодоступным узкоспециализированным информативным контентом её интерфейса, гностический ресурс учащегося не должен содержать непроверенные и неверифицируемые сведения, быть наполнен «репостами» и представлять собою фактический плагиат. Это, разумеется, отнюдь не процесс обучения как таковой. Методологически значимо в предложенной интерактивной форме общения сохранить наиважнейший дидактический peсурс: систематизацию и взаимообусловленность знаний. В критериях философской науки познание не становится простым «приращением сведений», информационным пулом. Ему предшествует социально-возрастной процесс постижения и субъективное стремление освоить реальность гнозиса антропосоциогенеза. Познание и в дистанционной форме обучения должно оставаться для учащихся экзистенцией, «пределом существования», ответом на вопрос «зачем?», переосмыслением, принятием нового, отторжением части своих заблуждений и апорий.

В рамках «онлайн» обучения преподавателю очень важно способствовать максимальной деформализации учебного процесса, созданию атмосферы коллективного знания. Это труднодостижимо в реальных условиях максимально унифицирующего, стандартизирующего и прагматичного процесса обучения, основанного на формализме предоставляемой отчетности и получаемых сведений, но целеполагание подлинного педагога неоспоримо. Оно предполагает, в частности, сохранение концептуальной системности в изложении материала, усвоения учащимися принципов организации комплексного научного знания, развитие у них понятийно-аналитического мышления, желания и умения думать - на основе саморефлексии, логики и критического анализа, сопоставления и этической оценки.

Наконец, наибольшим достижением педагога в рамках именно дистанционного обучения становиться формирование у учащихся фундаментального навыка чтения больших объемов текста, размышления над ним: чтение книг и сама способность к чтению, а и критерием «человекомерного» образования затем - к идеаторике, становится важнейшим приоритетом. 
Между тем, существующая тенденция построения параметров дистанционного обучения всё более характеризуется намечающимся в её рамках догматизмом, отсутствием инициативы, предельной упрощённостью когнитивных запросов. Главной нормативной задачей такого учебного процесса подразумевается не его эффективность и легкость получения знания, а контроль за работой преподавателя. Необходимо не проецировать эти затруднения на весь образовательный контент высшей школы, а в условиях максимальной информационной насыщенности предоставить учащимся шанс познакомиться с самыми передовыми фундаментальными теориями, формирующими современную научную парадигму, с новыми проблемами философского, гуманитарного, естественнонаучного и IT- знания.

Ситуация дистанционного обучения в интерактивной форме в значительной степени лишает преподавателя дисциплины «Философия» дидактического арсенала в проведении лекционного курса и приема экзамена. Мотивация основного контингента учащихся к получению систематического и углубленного знания ощутимо снижается. Живое общение, предполагающее вербальное и невербальное взаимодействие как совокупность обучения личности, уходит из практики, актуализируясь нейтральным информационным рядом презентаций, делающим излишним даже включение видеокамеры гаджета. Такой вынужденный интерфейс методически несостоятелен для образования когнитивных качеств. Необходимо также учитывать краткость концентрации внимания учащихся и минимальный объем предоставляемого им для ознакомления текста. Это параметры коррекционной и ситуационной педагогики.

Реальный учебный процесс, целеполагающий развитие мыслительных способностей, критический анализ, непрерывность рассуждений, детерминированных фундаментальностью знаний, предметным теоретизированием по сложной проблематике долговременного гностического поиска, не должен подменяться в дистанционном формате обучения поверхностным информационным «слайдингом» (slide-скольжением), стремлением к формальности информационного отклика, репостингу и плагиату.

Дистанционное чтение лекционного курса на имеющихся информационных платформах неудобно и трудоемко, его КПД низок: время, 
энергия и здоровье, т.е. самое ценное, что есть у учащегося и у преподавателя, затрачиваются на порядок больше без погружения в материал и без построения необходимого общего когнитивно-психоэмоционального взаимодействия субъектов обучения.

Задача самостоятельного освоения дисциплины «Философия» делает необходимым целенаправленный индивидуальный поиск системообразующего знания в дифференцированном информационном пространстве (т.е. без учета предпочтительной выборки), следовательно, наилучшая роль преподавателя в этом случае - роль компетентного навигатора.

В методологическом смысле преподавателю необходимо исходить от того факта, что человеческая мысль рождается на базе многомерной когнитивной аналитики. Знание представляет собой уникальный, созидаемый каждым субъективно и целенаправленно формируемый, отличительный видовой (Sapiens) теоретико-рефлективный ресурс человеческой личности, процесс долговременного развития мозга и результат его накопительной практико-аналитической работы по классифицированию, систематизации, критическому осмыслению, раскрытию спектра гипотез, усложнению вариативности смыслов. Сомнение и постоянный творческий поиск изначально присущи природе человеческого мозга как биологической базы сознания и функциям его плодотворной эволюции. Чем сложнее поставленная задача, тем дольше длится осмысление проблемы, чем оно вариативнее, тем больше оснований констатировать, вследствие этого, развитие глубинной рефлексии личности, ее когнитивный рост, проявление ее сущностных характеристик.

Немаловажно отметить, что в условиях дистанционного обучения дисциплина «Философия» видится принципиально значимым когнитивнокоммуникативным фактором учебного процесса в высшей школе, фокусируя накопленный в социуме интеллектуальный потенциал учащегося и активизируя его перманентную социализацию. Интеллектуальные функции человеческого мозга являются результатом длительной социальной эволюции личности с целью ее максимальной адаптации в коллективной среде. Критерий «социальности» для человека фактически критерий его фундаментального ума: насколько он коммуникабелен и многопланов в общении с разными представителями общественных групп, настолько он причастен к «коллективному знанию». Насколько он мотивирован попросить, узнать у другого, настолько больше его шанс к единению, компромиссу, диалогу, к 
пониманию сути происходящего. Он сразу видит и соотносит целостность и сложность определенной проблемы, коллизии отношений, наконец, осознаёт «другого» человека - он для него, вопреки Ж.П. Сартру, «не ад», но, в первую очередь, индивидуум и ценность. В ситуации тотальной интернеткоммуникации и максимальной доступности информации индивидуальная ценность «другого» человека как незаменимого субъекта социального взаимодействия, как носителя иных или аналогичных смыслов нивелируется. В «цифровом обществе» «другой» не нужен, и вместе с ним пропадает ценность целостного знания, ускоряется процесс его фрагментированности, вынужденной фильтрации.

Дисциплина «Философия» становится качественным выражением «человекомерной» образовательной среды, характеристикой антропогенного вектора обучения. Его кардинальным отличием от иных сфер теоретического и прикладного знания наряду с развитием памяти, воображения и саморефлексии становится возможность создания субъективной реальности «другого», построение «живых» идеаторных и креативных конструкций, личностного «макромира» интеллектуального творчества.

В этой связи методологические и социальные задачи преподавателя заостряются актуальностью их реализации в «цифровом пространстве»: необходимо как можно полнее сформировать мировоззрение учащихся, проиллюстрировать историю философского знания и всесторонне охватить его дискурс, в совокупности рассмотреть самые значимые вопросы онтологической, гносеологической, этической, социокультурной проблематики.

Названные задачи пока ещё объективно решаемы в реалиях российской социокультурной среды, сформированной классической методикопедагогической парадигмой отечественной образовательной традиции, акцентированной на фундаментальном этосе и гнозисе, на философии обучения, целеполагающей человека символикой высочайшего онтологического статуса.

\section{БИБЛИОГРАФИЧЕСКИЙ СПИСОК}

1. Васягина Н. Н. Человек как субъект социокультурного пространства // Педагогическое образование в России. - 2013. - № 4. - С. 7-14.

2. Дронова Е. Н. Технологии дистанционного обучения в высшей школе: опыт и трудности использования // Преподаватель XXI века. - 2018. № 3. - С. 26-34. 
DOI

УДК 159.9

Белянская Татьяна Эдуардовна, преподаватель, Воронежский государственный лесотехнический университет имени Г.Ф. Морозова

\section{ЦИФРОВОЕ ПРОСТРАНСТВО КАК СРЕДСТВО КОММУНИКАЦИИ СТУДЕНТОВ}

\section{DIGITAL SPACE AS A MEANS OF STUDENT COMMUNICATION}

Аннотация: В данной статье рассматривается понятие «цифровое пространство». Отмечаются положительные и отрицательные стороны влияния данного явления на современное студенчество.

Abstract: This article discusses the concept of "digital space". The positive and negative aspects of the influence of this phenomenon on modern students are noted.

Ключевые слова: цифровое пространство, коммуникация, студенчество, киберпространство, виртуальность

Key words: digital space, communication, students, cyberspace, virtuality.

Цифровое пространство сегодня - это поле для взаимодействия, среда существования, неотъемлемая сторона жизнедеятельности.

Пространство воспринимается человеческим сознанием многосторонне, как единение разнородного [4, С. 48]. Цифровое пространство - это часть информационного пространства общества, которое характеризуется виртуальностью, одна из составляющих киберпространства.

Цифровое пространство - это абсолютно новый тип реальности, который во многом уподобляется термину «виртуальная реальность», включающий в себя культурные и аксиологические компоненты [4, С. 49]. Цифровое пространство динамично, изменчиво, увеличивает охват влияния на новые социальные группы и расширяет территориальные границы. По мнению И.А. Добровольской, понятие цифровое пространство созвучно с понятием информационное пространство [1, С. 142].

(C) Белянская Т.Э., 2021 
С.Э. Зуев под информационным пространством понимал информационную действительность, выраженную в правилах игры, новом типе субъектов деятельности в информационном поле [3, С. 52]. Согласно его теории, без информационного пространства невозможны глобальные изменения, прогресс в обществе, стратегии модернизации.

Цифровое пространство формирует определенный тип коммуникативных взаимодействий, имеющих отличие в способах обмена информацией, основывающихся на иных культурных нормах, присутствующих в реальных взаимодействиях.

Цифровое пространство имеет две составляющие: инфраструктуру и ресурсы. То есть техническое оснащение любой современной деятельности включает в себя применение компьютеров, гаджетов, компьютерных сетей, программного обеспечения. Результатом такой деятельности являются оцифрованные образцы физических объектов, базы данных. Осуществление цифрового взаимодействия происходит с помощью определенных методов управления, процессов и технологий.

Развитие цифрового пространства реализует долгосрочные цели [2]:

- подъем и развитие экономики;

- формирование глобальной цифровой экономики рынков;

- прогресс человеческих ресурсов;

- увеличение жизни и повышение демографии в стране;

- уменьшение дефицита благ.

По мнению А.П. Сидоровой «цифровое пространство» виртуально включает в себя разноплановую информацию, объединяет разносторонние действия, используя персонализированные автоматические средства, что позволяет быстро и удобно обрабатывать и передавать информацию [4, С. 50].

Молодежь больше вовлечена в цифровое пространство нежели старшее поколение. Современные 20-летние люди, которые сейчас получают высшее образование - это дети, которые выросли с гаджетами, их мышление определяется понятиями и умозаключениями, связанными с виртуальным миром. Порой реальный и виртуальный мир для студенческой молодежи неразделим и они с легкостью переходят из одного в другой.

Цифровое пространство - это картинка, заранее навязываемый образ, который позиционируется, как идеальный. Таким образом, у молодого 
поколения искажаются ценностные ориентиры в формировании личностной идентичности, происходит постоянное сравнение себя с шаблоном.

Еще одна опасность таится в неразборчивом пользовании цифровым пространством, в котором нет фильтров и порой сложно различить правдивую информацию от искаженной и вредоносной. Цифровое пространство можно смело назвать сегодня агентом социализации, оказывающим глобальное воздействие на формирование психических процессов студенчества и определяющее их жизненные ориентиры.

Мною был проведен опрос студентов 2 курса Воронежского лесотехнического университета по теме использования социальных сетей, которые заполняют цифровое пространство и их основная цель устранить вакуум в общении. Результаты были получены ошеломляющие: 100 \% студентов используют социальные сети, 76 \% студентов тратят на них время более 3 часов в день и 89 \% студентов используют социальные сети именно для общения. Такое положение вещей может привести к тому, что у большинства молодых людей может утратится навык межличностного общения и даже развиться страх общения в реальном мире. Частое времяпровождение в социальных сетях обедняет словарный запас, лексика пополняется словамипаразитами, упрощаются языковые фразеологизмы.

Конечно, общение в цифровом пространстве имеет и положительные стороны: расширяет границы коммуникации, помогает установить связи по интересам, найти единомышленников и даже помогает стать знаменитым и популярным, создав обширную лояльную аудиторию вокруг себя. В цифровом пространстве легко быть смелым, легче стать принятым и выслушанным, откидывая условности, но это опять же уход от реальности, некая игра, которая может быть не принята в обществе, где ты открыт и без маски. Такое погружение в цифровое пространство получило название киберзависимости.

Еще одна опасность, которая таится в цифровом пространстве - это массовое распространение агрессивного и деструктивного контента в сети, возможность деятельности террористических и экстремистских организаций. Это явление особенно опасно для молодого поколения, которое еще в поиске направленности своей личности и выборе жизненных целей. Пролистывая новостные ленты, молодежь подсознательно зомбируется той информацией, которую видит. 
Студент, не обладающий достаточно развитым уровнем самоконтроля может провести в интернете неограниченное время.

Необходимо отметить так же, что цифровое пространство несет в себе и положительные стороны: это быстрое получение нужной информации для обучения в ВУЗе, возможность узнать мнение известных людей по актуальным вопросам современности, даже прикоснуться к их личной жизни и получить обратную связь. Цифровое пространство может заинтересовать и доступно объяснить сложные научные явления, это расширяет кругозор и повышает интеллект, много интересных и познавательных фактов мы получаем из Интернет-пространства. Сейчас цифровое пространство - это возможность заработать деньги, начать свой бизнес или найти работу, что очень важно для формирования профессиональных навыков студентов.

Так же цифровое пространство - это удобство в быту, сейчас можно не носить тяжелые сумки из магазина, а покупать товары с доставкой на дом, это высвобождает большое количество времени для других сфер деятельности.

Но также стоит отметить, что использование новых цифровых технологий может привести к очень серьезным угрозам и рискам. Расширение цифровых услуг и индивидуализация многочисленных видов услуг повышают риск мошенничества, одновременно снижая контроль над пользователями или поставщиками.

Подводя итог, хочется сказать, что современное общество меняется, меняется в сторону цифровизации, эти изменения необходимо принять и адаптировать. Положительных моментов, которые несет в себе цифровое пространство гораздо больше, чем негатива. Задача педагогов и психологов образования в обеспечении безопасности образовательного пространства от пагубного влияния киберпространства, а не в запретах и упреках. Использование цифрового пространства - это использование информации, главного ресурса в самосовершенствовании. Но, как и в реальной жизни, так и в киберпространстве нужны фильтры, ограничения, подсказки старшего поколения, воспитание молодежи. Очень важно не терять эмоциональную связь родителей и наставников с молодежью, тогда заинтересованность подрастающего молодого поколения цифровым пространством будет исключительно в познавательном русле и оградит от заведомо опасного контента. 


\section{БИБЛИОГРАФИЧЕСКИЙ СПИСОК}

1. Добровольская И. А. Понятие «информационное пространство»: различные подходы к его изучению и особенности // Вестник РУДН. - Серия Литературоведение. Журналистика. - 2014. - № 4. - С. 140-147.

2. Жилкин В. В. К вопросу понимания сущности термина «информационное пространство» // Центр системного анализа. URL: http://rosanaliz.ru/ Post.aspx?Post=107 (дата обращения: 15.04.2021).

3. Модестов С. А. Информационное противоборство как фактор геополитической конкуренции. - М.: Московский общественный научный фонд: Издательский центр научных и учебных программ, 1999. - 64 с.

4. Сидорова А. П. Понятие цифрового пространства и его характеристики. Возможности и угрозы использования цифрового пространства // Научный диалог: молодой ученый. Сб. научн. тр. по мат. XXVIII междунар. научн. конф. - СПб., Международная Объединенная Академия Наук, 2020. - С. 48-55. 


\title{
DOI
}

УДК 37.012, 37.022

\author{
Алесин Игорь Иванович, \\ кандидат философских наук, \\ преподаватель-организатор
} основ безопасности жизнедеятельности, МБОУ СОШ №14 городского округа г. Воронеж

\section{ТЕНДЕНЦИИ К СИМУЛЯКРИЗАЦИИ ОБРАЗОВАТЕЛЬНОЙ СРЕДЫ}

\section{TRENDS TO SIMULACRIZATION OF THE EDUCATIONAL ENVIRONMENT}

\begin{abstract}
Аннотация: В статье подвергаются анализу проблемы, связанные с воспитанием личности в условиях современной образовательной среды. Парадигмарно исследование строится по принципу разделения образовательных технологий на эффективные и на неэффективные. Применительно к последним используется термин «симулякр»,

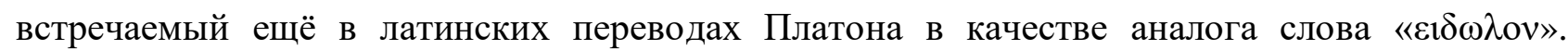
Используемые в образовательной среде цифровые технологии тогда и только тогда могут способствовать личностному развитию, когда они связывают обучающихся с историей их собственной страны, подчас противоречивой, но одновременно влекомой к вечной истине.

Abstract: The article analyzes the problems associated with the upbringing of a personality in the modern educational environment. Paradigmatically, the study is based on the principle of dividing educational technologies into effective and ineffective. With regard to the latter, the term "simulacrum" is used, which is found in the Latin translations of Plato as an analogue of the word " $\varepsilon 1 \delta \omega \lambda \circ v$. Digital technologies used in the educational environment can then and only then contribute to personal development when they connect students with the history of their own country, sometimes contradictory, but at the same time attracted to the eternal truth.
\end{abstract}

Ключевые слова: история, образовательная среда, симулякр, культурные коды, цифровые технологии, любовь к Родине, истина

Key words: history, educational environment, simulacrum, cultural codes, digital technologies, love for the homeland, truth

Проблема социальных симулякров [2] начала активно изучаться в XX в. Последние также могут являться следствием виртуализации современного общества [1, С. 123]. Реальное положение вещей кодируется, шифруется, 
мистифицируется и маскируется различными способами и под разными предлогами со стороны различных групп, носителей частного интереса [2, С.3]. Всё это имеет непосредственное отношение и к образовательной среде.

Цифровизация, став неизбежным следствием развития современного общества, обрекает всех тех, кому небезразличны вопросы, связанные с нравственным развитием личности, на поиск выхода из сложившейся ситуации. Современная молодежь фактически теряет интерес к истории своей собственной страны, перестаёт понимать те культурные коды, которые были очевидны для их отцов и матерей, бабушек и дедушек, и эта ситуация со временем усугубляется. Современная неоклассическая постмодернистская культура отодвигает на периферию вопросы, связанные с историей родного государства, подменяя их концепциями, в которых нет даже оригинала. Мышление как школьников, так и студентов вузов, с которыми не ведётся пристальная и детальная историко-логическая проработка, симулякризуется до банального воспроизводства того, что они встречают в своих социальных сетях, мессенджерах и видеохостингах. Такого не должно быть. Современная образовательная среда позволяет рассматривать обучающихся в качестве личностей, способных не только к воспроизводству ранее слышанного или виденного материала, но и к его анализу с помощью тех культурных кодов, которыми пользовались еще их бабушки и дедушки. Причём в последнем нет ничего плохого.

Как бы это банально ни звучало, но истина все же существует. Она может рассматриваться и в качестве универсального концепта [3, С. 26], и как исполнение интенциональности [4, С. 70]. Такое двоякое понимание истины можно применить и к образовательным технологиям. Первое выражает как целостное восприятие мира, так и индивидуальное проявление человека в нём, возможное как любовь к Родине. Второе основано больше на космополитическом настроении, поскольку дифференциальные части рассматриваются как бы под общим знаменателем. Иными словами, в первом случае речь идёт об обращении обучающихся к своему мышлению, во втором же случае - об обращении обучающихся к собственному сознанию. Безусловно, одно невозможно без другого, но те образовательные технологии, которые фокусируются только лишь на сознании обучающихся, безусловно, осуществляют работу деструкции мышления обучающихся. И поэтому уместно 
говорить о симулякризации образовательной среды, если в ней не эксплицируется историческое мышление.

Для того чтобы понять, перед какими вызовами стоит современное образование на пути цифровизации учебного процесса, следует рассмотреть следующую схему:

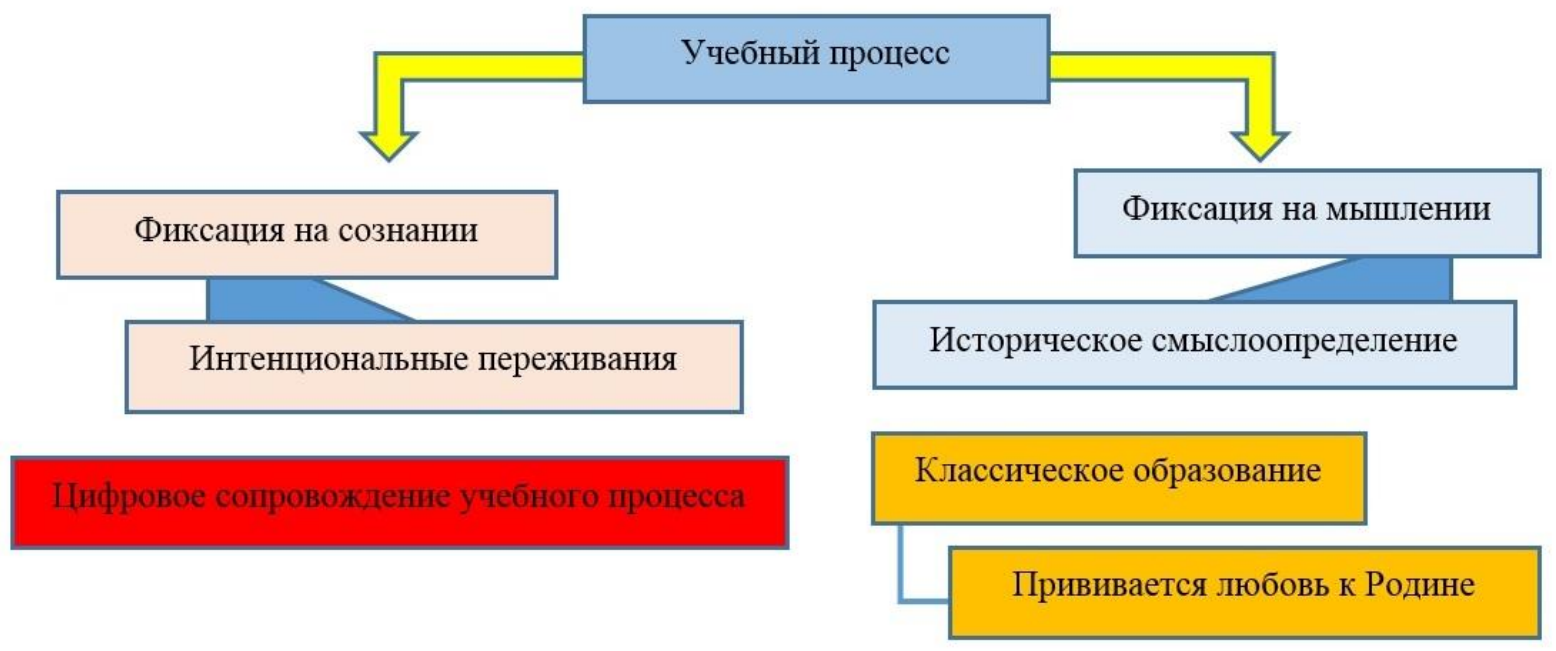

Цифровизация образовательной среды является условием, в котором могут быть применены самые различные образовательные технологии, однако чисто формально она является средством воздействия на сознание обучающихся, поскольку первично речь идёт о визуальном и аудиарном способе усвоения информации. Историческое бытие при последнем никоим образом не задействуется, поэтому, чтобы нивелировать данный негативный момент, необходимо сопровождать абсолютно все читаемые курсы исторической хронометрией и делать на ней ключевой акцент в познании. В противном случае образовательная среда становится площадкой, на которой личностное и историческое отделяются и отдаляются друг от друга.

В общем и целом, речь идёт о том, каким образом образовательная среда может трансформироваться в симуляцию. С одной стороны, этому способствует релятивизм в смысле поиска истины, с другой же стороны, сам феномен цифровизации образования уже содержит в себе симуляцию, однако, несмотря на последнее, при историческом обосновании излагаемого материала учебный процесс может быть, с технической точки зрения, организован таким образом, чтобы познание истины становилось целью, ради которой обучающиеся стремятся к знанию. 


\section{БИБЛИОГРАФИЧЕСКИЙ СПИСОК}

1. Бодров А. А. Виртуальная реальность как когнитивный и социокультурный феномен: дис. ... докт. филос. наук: 09.00.01. - Самара, 2007. -293 c.

2. Ким И. В. Социальные симулякры и их исторические типы: дис. ... канд. филос. наук: 09.00.01. - Екатеринбург, 2008. - 137 с.

3. Максимчик О. А. Функционально-семантическое и когнитивнопрагматическое описание концепта «истина»: на материале современного английского языка: дис. ... канд. филол. наук: 10.02.04. - Самара, 2010. - 230 с.

4. Степаненко С. Б. Автономия литературы в контексте герменевтикофеноменологического понятия истины: дис. ... канд. филос. наук: 09.00.01. Томск, 2004. - $172 \mathrm{c}$. 
DOI

УДК 37.012, 37.022

Гришин Андрей Александрович, кандидат философских наук, старший преподаватель, Воронежский государственный лесотехнический университет имени Г.Ф. Морозова

\author{
ИНФОРМАЦИОННОЕ ПРОЕКТИРОВАНИЕ УЧЕБНОЙ \\ ДЕЯТЕЛЬНОСТИ ОБУЧАЮЩИХСЯ В ОНТОЛОГИЯХ ВОЛЕВОГО \\ УСИЛИЯ И ИНТЕРТЕЙМЕНТА
}

\title{
INFORMATION DESIGN OF LEARNING ACTIVITIES OF STUDENTS IN ONTOLOGIES OF WILLED EFFORT AND ENTERTAINMENT
}

\begin{abstract}
Аннотация: В статье подвергаются детальному анализу концепции организации учебного процесса в предметных рамках волевого развития и в предметных рамках эмоционального отвлечения. Первое рассматривается в алгоритмическом смысле, в то время как второе опосредуется онтологической системой эвристического содержания и направленности. Проблема соотношениях двух компонентов учебной деятельности обучающихся эксплицируется в феномене трансформации классической модели образования в цифровое и в техническое интертеймент-обеспечение учебного процесса. Последнее мыслится как необходимое и обусловленное кризисами современного общества, ориентация же исследования делается возможной вследствие переориентации мышления обучающихся [!] с феноменального (чувственного) возможного как интертеймент [в учебном процессе] на формирование волевого усилия: при этом мыслимое в эвристической онтологии развлечение (entertainment) c точки зрения целеполагания самих обучающихся опосредуется экзистенциальным порывом, обозначаемым через philosophia moralis или через когнитивное снятие [Aufhebung/Sublation «по Гегелю»].

Abstract: The article presents a detailed analysis of the concept of organizing the educational process in the subject framework of volitional development and in the subject framework of emotional distraction.

Ключевые слова: информационное проектирование, волевое усилие, когнитивное снятие, учебный процесс, интертеймент, логическая абстракция.

Keywords: information design, volitional effort, cognitive withdrawal, learning process, interteiment, logical abstraction
\end{abstract}

(ㄱ Гришин А.А., 2021 


\section{Проблемы цифровизации учебного процесса}

Основной проблемой в современной системе общего и высшего образования в Российской Федерации является проблема качественного развития абстрактно-логического мышления обучающихся с последующей профильной ориентацией последних в сферу естественно-научного и гуманитарного знания. Реализовать поставленную задачу можно подвергнув концептуализации мышление современного человека с необходимостью взаимодействующего с аппаратными средствами, такими как смартфоны, компьютеры, банкоматы и другие технические устройства, обладающие графическими интерфейсами. Трудность состоит в том, что не всегда при использовании технических устройств человек задействует абстрактнологическое мышление. Функционально вовлечённые в образовательную деятельность тинэйджеры и студенты, используют выше обозначенные графические интерфейсы для получения феноменально (чувственно) окрашенного удовольствия, способствующего эмоциональной разрядке. Такие сервисы как TikTok, Instagram, ВКонтакте и Telegram, став кроссплатформенными обеспечивают при этом особое понимания бытия среди их пользователей не столько содержательно, сколько формально: перцептивно формуя оптическую модель восприятия окружающего мира. Следует заметить, что стиль мышления формируемый выше обозначенными сервисами диктует и сам способ проведения учебного процесса, поскольку в рамках последнего следует обращаться к формально-логическим законам. Превалирование феноменального опыта над опытом построения логических абстракций не сулит ничего хорошего ни для тинэйджеров, ни для студентов высших учебных заведений. Однако позволить обучиться последним логическому мышлению в интерактивном формате организации учебного процесса достаточно проблематично, поскольку этому способствовала классическая модель образования, которая осуществляла перекодирование как сенсорной системы человека, так и его нервной системы. В интерактивном формате обучения речь идёт о получении качественного феноменального опыта, который необходим при обучении только в том случае, когда мышление обучающиеся фактически перегружено той или иной информации по излагаемому курсу. Графически это отображается следующим образом (см. рис. 1). 


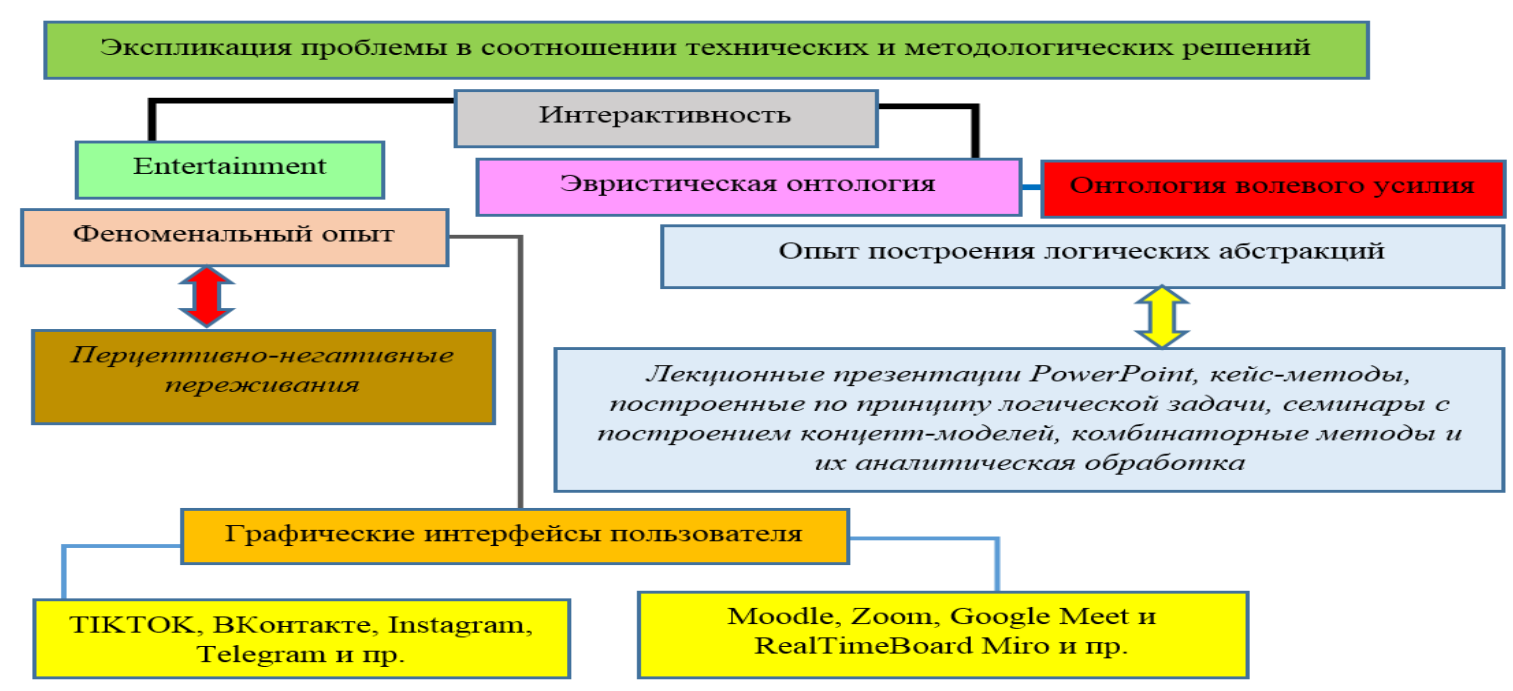

Рисунок 1

Первоначально, информация по излагаемому в процессе обучения курсу должна совмещаться с тем стилем мышления обучающихся к какому они привыкли в сети Интернет с той целью, чтобы перекодирование сенсорной и нервной систем в процессе обучения происходило в максимально комфортных для последних условий. Экспликация же логического способа формализации информации в рамках излагаемого курса не должна навязываться, но актуализироваться как сопутствующая по той простой причине, что только таким образом можно сформировать доверительную атмосферу в процессе обучения между кураторами учебной деятельности и обучающимися. Таким образом, феномен интертеймента в процессе учебной деятельности должен облекаться в ненавязчивую формально-логическую оболочку, причинноследственная связь в рамках которой должна определяться не извне, но личностно самими обучающимися. Следует отметить, что соотношение эвристических моделей обучения с классическими моделями интерактивного взаимодействия с аудиторией в ходе учебного процесса является общемировой тенденцией. Например, в связи с переходом на дистанционный формат обучения, вследствие пандемии коронавирусной инфекции, вызванной коронавирусом SARS-CoV-2, как и с обратным возвращением в естественный формат обучения, аналитиками Министерства Просвещения Российской Федерации, аналитиками Министерства науки и высшего образования Российской Федерации, а также российскими учёными были сделаны существенные выводы о целях и о средствах организации учебного процесса в 
периоды глобальных общемировых кризисов. В одном из своих интервью информационному агентству РБК в апреле 2020 года министр науки и высшего образования Российской Федерации В.Н. Фальков обратил внимание на сложности в работе преподавателей в удаленном формате обучения, касающиеся организации коллективной работы, поддержания внимания студентов, при этом подчеркнул, что сам процесс обучения должен продолжать традиции обычного, т.е. задача преподавателей и в новых условиях «сделать интересным обучение в формате, когда у тебя, по существу, эмоциональные и интеллектуальные моменты идут асинхронно» [1, С. 198; 3]. При этом не следует забывать, что интерактивные форматы в эвристических онтологиях и в онтологии развития волевого усилия должны совмещаться в ориентации психопрофилактического стиля мышления. Соответственно, реализуемый в образовательной системе Российской Федерации компетентностный подход может быть значительно расширен: в него могут быть вложены в качестве некоторых множеств психопрофилактические мероприятия и различные методологические решения профильной направленности на базовом и вариативном уровнях федерального государственного образовательного стандарта [2, С. 32]. Фактически связанные с пандемией коронавирусной инфекции кризисные события в системе российского образования показали, что цифровизация учебного процесса в вузе не сводится только лишь к наличию аппаратного обеспечения и программного обеспечения с удобными и понятными для преподавателей графическими интерфейсами, но что вопрос методологии учебного процесса в цифровую эпоху должен детально прорабатываться в онтологических рамках философской формы мировоззрения.

Речь, безусловно, идёт и об организационно-методологической перестройке мышления самих преподавателей: с началом карантинных мероприятий в период эпидемии коронавирусной инфекции COVID-19 для профессорско-преподавательского состава стал неизбежным выбор инструментов и технологий для запуска изучения дисциплины в дистанционном режиме [8, С. 37], однако образовательные технологии в классическом и в дистанционном образовании отличаются друг от друга и до сих пор не было разработано ни философского обоснования, ни методологической практики каким образом профессорско-преподавательский состав должен совмещать эмоциональные, интеллектуальные и эвристические 
компоненты в дистанционной и смешанной моделях образования. И несмотря на успехи в последнем многие исследователи констатируют факт, что в условиях полного удаленного формата обучения практически невозможна реализация одного из главных постулатов педагогической мысли воспитывающей, формирующей, развивающей и продвигающей роли самого процесса обучения [1, С. 200].

\section{Онтологическое изменение обстановки с организацией учебного процесса в классической и смешанной моделях образования}

Динамика эмоционального и когнитивного развития в дистанционный период обучения в 2020 и в 2021 году не была успешной. Это было вызвано отсутствием проработки алгоритмов и рекомендаций со стороны вышестоящих органов в отношении тех вызовов, перед которыми оказалось современное общество. Негативные стороны дистанционного образования могут быть рассмотрены и детально проанализированы при аппаратно-техническом сопровождении учебного процесса в рамках классической модели образования. Так графические интерфейсы, используемые тинэйджерами и студентами для развлечения и для коммуникации (ТІКТОК, ВКонтакте, Instagram, Telegram) могут стать онтологической основной для построения среды, в рамках которой наиболее успешной будет, как организация учебного процесса в рамках классической модели образования, так и смешанной, и полностью дистанционной. $\mathrm{C}$ технической точки зрения эта проблема решается архитекторами программного обеспечения, исследовательский же интерес представляет философское обоснование этого явления. Такие графические интерфейсы как Moodle, Zoom, Google Meet и RealTimeBoard Miro разрабатывались для упрощения жизни обывателей, однако их использование в образовательной среде накладывает отпечаток на организацию учебного процесса в целом. Это касается, в первую очередь, значительной феноменализации мышления обучающихся, фактически отказывающихся от логического способа мышления. На графической схеме выше показана тонкая грань между эвристической характеристикой познания и развлечением (entertainment). Если эвристическая онтология не работает или работает слабо при дистанционном или смешанном типе обучения, частично уместно поднять вопрос о том, чтобы трансформировать учебный процесс в entertainment в чистом виде. Тенденция к этому прослеживается довольно очевидно, когда в 
период пандемии коронавирусной инфекции, вызванной коронавирусом SARS$\mathrm{CoV}-2$, значительным образом снизились показатели психологического состояния [5; 9], как среди тинэйджеров и студентов, так и среди профессорскопреподавательского состава в высших учебных заведениях. Данная проблема может быть разрешена при разработке таких образовательных технологий, которые, с одной стороны, будут формировать экзистенциальный порыв к обучению среди обучающихся, a, с другой стороны, формировать у них довольно ясно осознаваемое волевое переживание. Целесообразно сказать и том, что несмотря на тот факт, что до сих пор не было разработано почти идеального графического интерфейса для реализации образовательных программ, тем не менее в рамках существующих графических интерфейсов [!] теоретически можно реализовывать как эвристические стратегии развития мышления обучающихся, так и укреплять их морально-волевой дух. При этом, имеющиеся методологии ранее обозначенных целей видятся в настоящий момент как рекомендации, которым можно следовать, но и которых можно, без особого труда, не замечать.

\section{Постепенное изменение образовательной среды в классической}

\section{и в дистанционной модели организации учебного процесса}

Современная социально-экономическая ситуация в стране и в системе образования такова, что традиционные формы получения образования и модели обучения не могут удовлетворить потребностей в образовательных услугах, обычно сконцентрированных в больших городах [7, С. 171]. Несмотря на серьёзную критику в адрес дистанционного и смешанного типа обучения, последние могут подвергнуться значительной трансформации. Позволить реализовать это может философская форма мировоззрения в аспекте онтологической концептуализации мышления обучающихся, следующих по пути тех или иных образовательных стандартов. В данный момент подлежат серьёзной проработке интерактивные компоненты при работе с графическими интерфейсами со стороны преподавателей и активность на них со стороны обучающихся. Никакая программа никогда не заменит живого человека, однако эвристизация мышления обучающихся может значительным образом не только снизить феноменальную (перцептивно-ориентированную) замкнутость обучающихся и нивелировать социальную депривацию, если она имеет место быть, но и послужить онтологическим основанием для формирования 
морально-нравственного волевого усилия среди обучающихся. Интерактивное качество обучения может этому способствовать, однако для формирования волевого усилия необходим ещё и формально-логический инструментарий, иногда и минимальный, который только и может подвергнуть концептуализации перцептивно-негативный феноменальный опыт самих обучающихся с их собственной стороны. Это должно осуществляться личностно, а не «nо указке» извне. Графически это выглядит следующим образом (см. рис. 2).

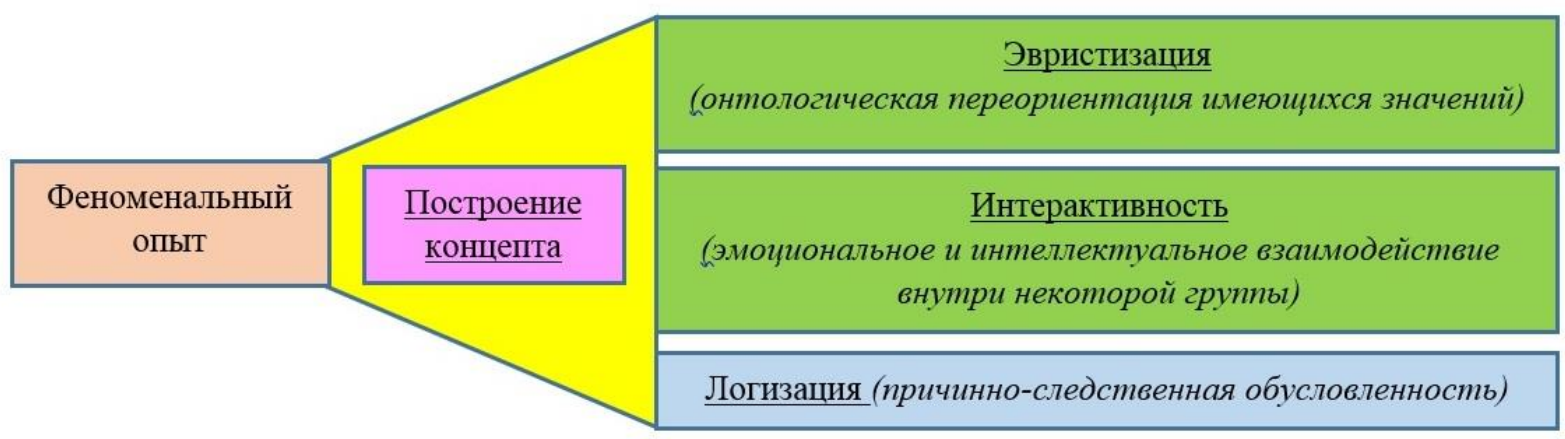

Рисунок 2

В любом случае графические интерфейсы в современном техническом мире, никоим образом, не могут рассматриваться как «абсолютное зло», форматы же цифровизации учебного процесса в нашей стране зависят от качества предоставляемых услуг и если в этих услугах не содержатся компоненты эвристизации мышления обучающихся, которые могут реализовываться как через сложные речевые конструкции (логический компонент), так и через эмоционально-коммуникативное их выражение (интерактивный компонент) сложно будет говорить об онтологических основания цифровых технологий вообще.

\section{Психопрофилактический компонент обучения при цифровом}

\section{сопровождении учебного процесса: феномен ностальгии над прошлым}

Психопрофилактические мероприятия могут содержаться в тех образовательных технологиях, которые уже онтологически вложены в читаемые курсы, дескриптивно возможные благодаря утверждённым рабочим программам. Достаточным основанием для организации психопрофилактических мероприятий может выступать герменевтика, понимание которой очевидно в феномене ностальгии. Новалис говорит в одном фрагменте: «Философия есть, собственно, ностальгия, тяга повсюду быть дома» 
[6, С. 86]. Иными словами, у этого понятия есть довольно сложная философская история. Цифровые технологии в некотором отношении упрощают учебный процесс, позволяя более детально познакомиться с экспликацией того или иного материала, однако они же предполагают своего рода примат «феноменального» или «чувственного» над «логическим» или же «имплицитно-выведенным». Нивелировать это позволяет онтологический конструкт ностальгии, поскольку абсолютно любой читаемый курс в рамках учебного плана фактически читается в исторической хронометрии. Т.е. реконструкция опыта предшествующих поколений в аутентичном значении необходима, а так как она составляет научный опыт добавление художественного элемента в экспликацию излагаемого материала способствует более детальному пониманию сущего, если речь идёт о технических дисциплинах и более детальному усвоению того или иного концептуального обобщения, если речь идёт о математике и корпусе социально-гуманитарных дисциплин.

Отметить также следует и то, что информационное проектирование учебной деятельности обучающихся в онтологиях волевого усилия и интертеймента может быть реализовано на практике вне зависимости от качества графических интерфейсов. На настоящий момент последние хоть и требуют качественной программной доработки тем не менее позволяют всё же нивелировать перцептивно-негативные переживания со стороны обучающихся. Это замечание уместно ещё и по той простой причине, что педагогическая база в современной системе образования имеет достаточно фундаментальное онтологическое основание, если говорить о накопленном педагогическом опыте работников этой сферы в Российской Империи и в СССР.

С логической точки зрения наличие психопрофилактического компонента в рамках учебного процесса может быть выражено как когнитивное снятие тех значений культуры (это может быть, как перцептивно-негативный опыт, так и опыт построения продолжительных абстракций, к которым обучающийся может быть не готов формально-логически), которые свидетельствуют об информационной перегруженности их носителей. В герменевтическом смысле это позволяет конфигурировать хронотоп (миросозерцание) обучающихся, если он не соответствует научной картине мира. Термин Aufhebung [когнитивное снятие - прим. авт.] в содержательном плане отражает преодоление субъектом 
границ культуры и возможность занятия им позиции внешнего наблюдателя по отношению к тем или иным феноменам культуры [4, С.17]. Именно с помощью снятия можно подвергнуть значительной нивелировки опыт одного лишь феноменального (чувственного) переживания. Графически это выглядит следующим образом (см. рис. 3).

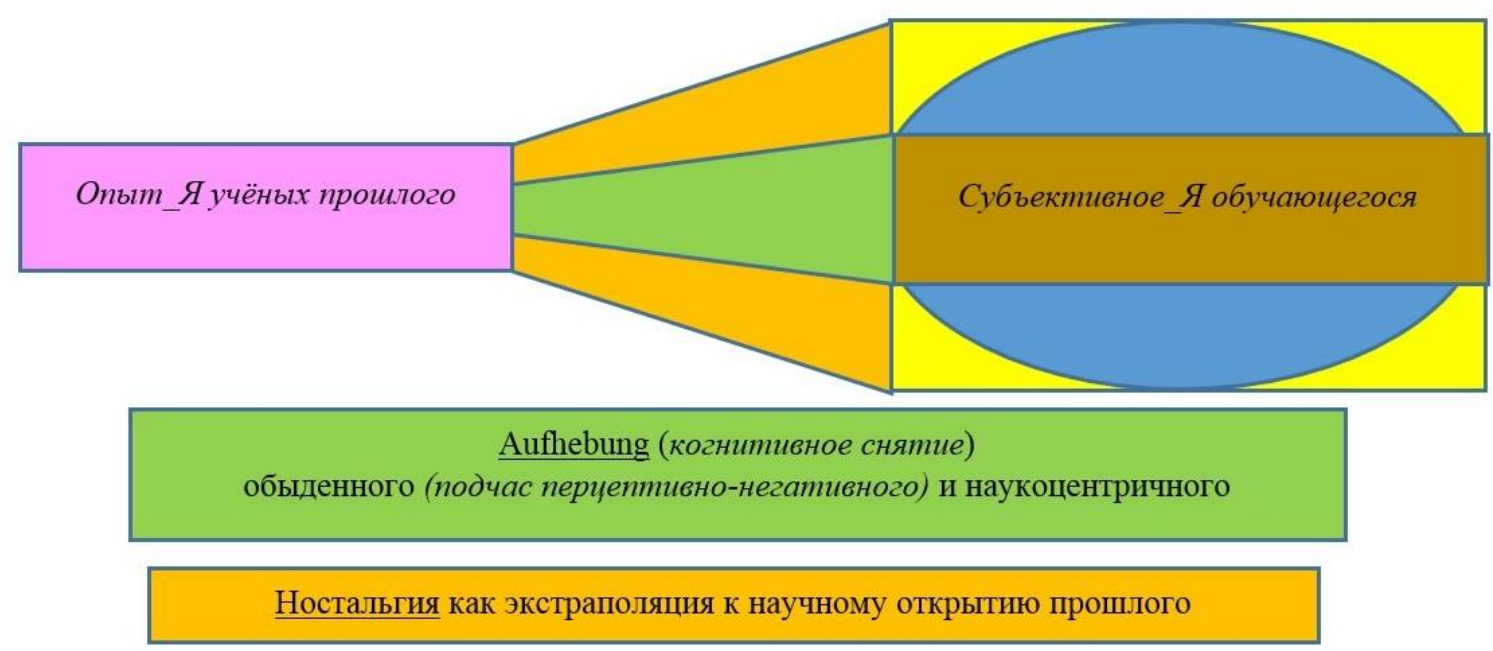

Рисунок 3

В дескриптивно-рациональной модели снятие не работает, поскольку гегелевское утверждение-и-отрицание выходит за пределы формальнологического закона непротиворечия в единении одного времени, в то время как при ностальгии как феномене бытия возможно не только когнитивное снятие имеющегося противоречия, но и обозначение двух диаметрально противоречащих картин мира: современно-научной и герменевтическим образом реконструируемой научной картины мира прошлого. В этом отношении уместно заметить, что имеется то достаточное основание, которое позволяет утверждать, что цифровизация современной классической модели образования, исходя из теоретических предпосылок по концептуализации этого феномена, может пройти успешно в условиях современного российского общества.

\section{БИБЛИОГРАФИЧЕСКИЙ СПИСОК}

1. Борзова Т. А. Уроки пандемии: цифровая трансформация высшего образования в формате удаленного обучения // Территория новых возможностей. - Вестник Владивостокского государственного университета экономики и сервиса. 2021. - № 1. - С. 195-208. 
2. Гришин А. А., Алесин И. И., Новикова 3. Н. Перспективы объектноориентированного подхода при создании архитектур организации учебного процесса и психопрофилактических мероприятий в цифровую эпоху // Сборник материалов Всероссийской научно-методической конференции с международным участием. Цифровизация образования: вызовы современности. - Чебоксары: Издательский дом «Среда», 2020. - С. 28-33.

3. Доронов И. Фальков анонсировал появление из-за вируса «другого высшего образования» / Деловой журнал «РБК»: [сайт]. - URL: https: // www.rbc.ru/society/09/04/2020/ 5e8edde 79a79470 aa3b361f7 (дата обращения: 23.12.2020).

4. Константинова Т. В. Модусы нигилизма в культуре транзитивного общества: автореф. дис. ... канд. филос. наук: 24.00.01. - Ростов-на-Дону, 2010. $-24 \mathrm{c}$.

5. Котляров В. Л., Иванов М. В., Козловская Г. В., Кремнева Л. Ф., Калинина М. А., Крылатова Т. А. Синдром изоляции у детей: социальные и клинико-психологические аспекты // Психиатрия и психофармакотерапия. 2020. - T. 22. - № 6. - C.37-41.

6. Хайдеггер М. Что такое метафизика? / Пер. с нем. В. В. Бибихина. М.: Академический проект, 2007. - 303 с.

7. Халиков А. А., Мусамедова К. А., Ибрагимова О. А. Анализ методов дистанционного обучения и внедрения дистанционного обучения в образовательных учреждениях // Вестник научных конференций. - 2017. - № 36 (19). - C. 171-173.

8. Шамшурина Е. О., Сазонов С. В. Опыт проведения видеоконференцсвязи в период дистанционного обучения на кафедре гистологии в весеннем семестре 2020-2021 учебного года // Вестник уральского государственного медицинского университета. - 2020. - № 3. - С. 36-39.

9. Юмашев А. В. Психологическая и клиническая патосемиотика пандемии коронавирусной инфекции (SARS-CoV-2): проблемы понимания и поиск корреляций // Азимут научных исследований: педагогика и психология. 2020. - T. 9 - № 2 (31). - С. 380-387. 
DOI

УДК. 159.9.07

Моисеева Мария Петровна, магистрант 1 курса, Воронежский государственный педагогический университет

\author{
ИССЛЕДОВАНИЕ ПСИХОЛОГИЧЕСКОГО БЛАГОПОЛУЧИЯ \\ СТУДЕНТОВ-ПСИХОЛОГОВ В УСЛОВИЯХ ДИСТАНЦИОННОГО \\ ОБУЧЕНИЯ
}

\title{
STUDY OF PSYCHOLOGICAL WELL-BEING OF PSYCHOLOGIST STUDENTS IN THE CONDITIONS OF DISTANCE LEARNING
}

Аннотация: В статье дана краткая характеристика структуры психологического благополучия личности. Рассмотрены основные концепции психологического благополучия личности. Описаны компоненты психологического благополучия в исследовании и описаны результаты исследования психологического благополучия студентов-психологов в условиях дистанционного обучения.

Abstract: The article provides a brief description of the structure of the psychological wellbeing of the individual. The basic concepts of psychological well-being of the individual are considered. The components of psychological well-being in the study are described and the results of the study of the psychological well-being of psychology students in the conditions of distance learning are described.

Ключевые слова: Психологи, студенты, студенты-психологи, субъективное благополучие, психологическое благополучие, дистанционное обучение

Keywords: Psychologists, students, psychology students, subjective well-being, psychological well-being, distance learning

В связи со сложившейся эпидемиологической обстановкой в мире, многие студенты перешли на дистанционную форму обучения. Она имеет свои специфические особенности, кардинально отличающиеся от аудиторной формы работы. Процесс удаленного преподавания является более трудоемким, поскольку для этого требуется крайне детальная организация учебных курсов. Наряду с этим, студенты обладают разными возможностями присоединения к видеоконференциям.

(C) Моисеева М.П., 2021 
Необходимо отметить, что главным фактором, влияющим на успешность обучения студента, является состояние психологического комфорта. Резкое изменение условий обучения может сказаться, в первую очередь, на его благополучии, самочувствии, самооценке, удовлетворенности жизнью, самосознании, которые, в свою очередь, имеют большое значение в психологическом здоровье. Негативное влияние дистанционного обучения на психологическое благополучие обучающегося может привести к ухудшению успеваемости по дисциплинам и снижению учебной мотивации. Данная проблема и определила цель нашего исследования: изучить психологическое благополучие студентов-психологов в период дистанционного обучения.

В конце 60-х годов XX века Н. Брэдберн [8, С. 122] ввел понятие «психологическое благополучие». В своей работе автор говорит о том, что модель психологического благополучия представляет собой баланс между положительным и негативными аффектами.

Рассмотрим модель психологического благополучия М. Ягоды. Обобщив исследования, М. Ягода привел модель к следующему вид: самопринятие (высокая самооценка), личностный рост, интегрированность, автономность, точность восприятия реальности, компетентность в отношении окружающей социальной среды [1, С. 32].

К. Рифф опираясь на данные Н. Брэдберна и М. Ягоды определила собственную модель психологического благополучия и создала опросник «Шкала психологического благополучия». Согласно К. Рифф [7, С. 69] психологическое благополучие - базовый субъективный конструкт, который отражает восприятие и оценку своего функционирования.

Нами было проведено исследование уровня психологического благополучия студентов-психологов, которые обучаются на втором и третьем курсе по направлению «Психология личности».

Объект исследования: психологическое благополучие личности.

Предмет исследования: психологическое благополучие студентовпсихологов в условиях дистанционного обучения.

Гипотезой нашего исследования выступило предположение о том, что студенты-психологи в условиях дистанционного обучения обладают средними или высокими показателями психологического благополучия: сниженным 
уровнем тревоги, средним уровнем толерантности к неопределенности, и средними результатами по шкале психологического благополучия.

Исследование проводилось на базе Воронежского Государственного Университета. В нем принимали участие студенты-психологи 2 и 3 курсов направления «Психология личности» в количестве 15 человек.

Психодиагностическим инструментарием выступили следующие методики:

1. «Шкала психологического благополучия» К. Рифф в адаптации Т.Д. Шевеленковой, П.П. Фесенко [6, С. 115]. Целью методики является определение уровня психологического благополучия и определения характера соотношения его компонентов.

2. «Шкала общей толерантности к неопределенности» Д. Макклейна в адаптации Е.Н. Осина. Целью данной методики является измерение склонности личности К жёсткой регламентации жизни и полной известности происходящего, либо открытости и неопределённости [3, С. 67].

3. Личностная шкала проявлений тревоги Дж. Тейлора в адаптации T.А. Немчина. С помощью данного метода можно выявить уровень личной тревожности испытуемого, под которой мы понимаем устойчивую характеристику личности, дающая представление о предрасположенности человека к проявлению тревожности [2, С. 22].

4. Определение деструктивных установок в межличностных отношениях В.В. Бойко. Цель - выявление деструктивных установок в межличностных отношениях испытуемых [2, С. 24].

В результате исследования мы получили следующие выводы.

Перейдем к рассмотрению результатов уровня психологического благополучия: 7\% студентов-психологов второго и третьего курса имеют высокий уровень психологического благополучия, 66\% имеют средний уровень, низкий уровень представлен у $27 \%$ студентов.

Высокие значения психологического благополучия личности говорят нам о позитивном функционировании человека, которое выражается в субъективном ощущении удовлетворенностью жизнью, реализации собственного потенциала, высокой интегрированностью и опосредованный системой отношений личности (с другими, миром собой). 
Студенты с низким уровнем психологического благополучия не имеют опыт позитивных близких отношений со значимыми людьми. Отношения с другими выстраиваются по принципу контроля. А также они не могут полностью принять себя, им тяжелее расставлять приоритеты в жизни.

Рассмотрим результаты, полученные в ходе изучения тревожности у студентов-психологов.

Большинство (86\%) студентов-психологов имеют средний с тенденцией низкому уровень тревожности. Следовательно, студенты не склонны испытывать тревогу, беспокойство в различных ситуациях. Следует отметить, что оставшаяся часть студентов (14\%) имеют средний с тенденцией к высокому уровень тревожности. Такие испытуемые уже в большей степени проявляют тревогу, беспокойство в повседневной жизни.

При рассмотрении результатов уровня толерантности к неопределенности, мы видим, что среднегрупповое значение равно 14 баллам. Чем выше значения, тем выше уровень толерантности к неопределенности. Сниженные значения свидетельствуют о том, что студенты склонны испытывать дискомфорт в трудных, неоднозначных ситуациях, не выносят неизвестность. Чаще всего они стараются привнести в свою жизнь однозначность и ясность. Повышенные значения показывают нам, что испытуемые способны находить различные пути выхода из трудноразрешимых ситуаций, их не пугают сложности и неоднозначность.

В результате исследования можно сделать следующие выводы: чем выше значения по каждому показателю, тем выше степень проявления той или иной деструктивной установки в межличностных отношениях у студентовпсихологов. Значение завуалированной жестокости равно 7 баллам, и выражает степень негативности по поводу окружающих, которые испытуемые прячут и не проявляют открыто в контактах. Значение открытой жестокости по отношению к людям (12), указывает на снисходительные оценки в отношении окружающих людей, а также мнение об окружающих может изменяться в зависимости от ситуации. У студентов-психологов обоснованный негативизм в суждениях о людях имеет средние значения (2), чем выше показатель, тем выше объективные отрицательные выводы о некоторых типах людей. Брюзжание также находится в средних значениях (2). Данный показатель свидетельствует о наличии или отсутствии склонности делать необоснованные 
обобщения негативных фактов в области взаимоотношений с партнерами. Негативный личный опыт, значение этого показателя равно 11 баллам. Данный показатель указывает, в какой мере испытуемым повезло иметь ближайший круг знакомых и партнеров по совместной деятельности, и был ли у них негативный опыт взаимодействия с ними.

Таким образом, можно сделать вывод об уровне психологического благополучия студентов психологов второго и третьего курсов в процессе дистанционного обучения. В преобладающем большинстве студенты имею средние показатели по таким параметрам как: уровень тревожности, уровень толерантности к неопределенности, уровень психологического благополучия. Выраженность деструктивных установок также находятся на среднем уровне. Данные факты указываю на целесообразность психолого-педагогического сопровождения студентов-психологов с целью повышения психологического благополучия личности.

\section{БИБЛИОГРАФИЧЕСКИЙ СПИСОК}

1. Бессонова Ю. В. О структуре психологического благополучия // Психологическое благополучие личности в современном образовательном пространстве: сб. статей / сост. Ю. В Братчикова. - Екатеринбург: Урал. гос. пед. ун-т, 2013. - С. 30-36.

2. Карелин А. Большая энциклопедия психологических тестов. - М.: Эксмо, 2007. - С. 22-24.

3. Осин Е. Н. Факторная структура версии шкалы общей толерантности к неопределённости Д. МакЛейна. // Психологическая диагностика. - 2010. - № 2. - С. 65-86.

4. Фомина О. О. Благополучие личности: проблемы и подходы к исследованию в отечественной психологии // Интернет-журнал «Мир науки». 2016. - Том 4. - № 6. URL: http://mir-nauki.com/PDF/53PSMN616.pdf (дата обращения: 14.04.2021).

5. Шамионов Р. М. Субъективное благополучие личности как субъекта социального бытия // Известия Сарат. университета. - Серии: «Философия. Психология. Педагогика». - 2014. - Т. 14 - № 1. - С. 80-84. 
6. Шевеленкова Т. Д., Фесенко П. П. Психологическое благополучие личности (обзор основных концепций и методика исследования) // Психологическая диагностика. - 2005. - № 3. - С. 95-121.

7. Ryff C. D. Singer B. Human Health: New Directions for the Next Millennium // Psychological Inquiry. - 1998. - Vol. 9. - P. 69-85.

Усынина Т. П., Цветнова А. Д. Психологическое благополучие студентов и факторы, его определяющие // Вестник Совета молодых учёных и специалистов Челябинской области. - 2017. - Т. 2. - № 1. - С. 122-124. 
DOI

УДК 159.937

Новикова Зоя Николаевна, старший преподаватель, Воронежский государственный лесотехнический университет имени Г.Ф. Морозова

\title{
ПСИХОЛОГИЧЕСКИЕ ОСОБЕННОСТИ ВОСПРИЯТИЯ ИНФОРМАЦИИ В РЕЖИМЕ ОНЛАЙН
}

\section{PSYCHOLOGICAL FEATURES OF INFORMATION PERCEPTION IN THE ONLINE MODE}

\begin{abstract}
Аннотация: настоящая статья рассматривает психологические особенности восприятия информации онлайн и оффлайн, формирование визуального образа и связь его с вербальной информацией. Один и тот же образ, размещенный в различные контексты, может приобретать несхожие, часто противоположные значения. Эта двойственность приводит к дивергентности мышления. В большинстве случаев визуальные образы соединяются с вербальным сообщением и образуются креолизованные тексты.

Abstract: this article examines the psychological features of the perception of information online and offline, the formation of a visual image and its connection with verbal information. The same image placed in different contexts can acquire dissimilar, often opposite meanings. This duality leads to divergent thinking. In most cases, visual images are combined with a verbal message and creolized texts are formed.
\end{abstract}

Ключевые слова: онлайн, оффлайн, визуальный образ, креолизованные тексты, символическое значение

Keywords: online, offline, visual image, creolized texts, symbolic meaning

В настоящее время уже трудно представить свою жизнь без всемирной сети. У средств массовой коммуникаций есть три функции: развлекать, информировать и обучать. Интернет сопровождает нас практически во всех наших делах, информирует о массе вещей - выстраивает маршрут, сообщает погоду, рассказывает, где купить какие-то товары и по какой цене, помогает общаться с людьми, которые живут далеко от нас и т.п. А еще интернет нас развлекает, предоставляет массу возможностей, например, можно не выходя из

(с) Новикова 3.Н., 2021 
дома посетить выставки, музеи, спектакли. Это стало сегодня таким привычным и необходимым. Образовательная функция - одна из важнейших, т.к. очень удобно слушать лекции на интересные для нас темы в удобное для нас время, в удобном формате, есть возможность побывать на семинарах или мастер классах у знаменитых специалистов. Образовательную функцию интернета все без исключения рассматривали только с положительной стороны, до тех пор, пока интернет-обучение не стало занимать все большее пространство и в какой-то степени конкурировать с традиционным обучением.

Одни говорили, что интернет-обучение - это масса возможностей, другие говорят, что интернет обучение ни в коем случае не должно замещать традиционные формы получения знаний, а только их дополнять.

Поклонники формата обучения онлайн в его защиту говорят, что изобретение печатного станка Гутттенбергом произвело феномен глубокого чтения, который противоречил природе человека. Ведь до этого времени у человека не было такой деятельности как чтение, во всяком случае, у большого количества людей. Человечество адаптировалось к новому формату восприятия информации, мало того чтение стало одним из условий существования человека. Слово, образ перевели в знаковую систему. А в настоящий момент письменное слово претерпевает изменение, оно перешло в новый канал восприятия. Просмотр информации с экрана компьютера отличается от чтения текста с печатного носителя. Чтение рассматривается, как сложная поисковая информационная деятельность. Просмотр компьютерной страницы начинается с левого верхнего угла, потом взгляд переносится вправо, затем по диагонали вниз, вверх и снова в правый угол. Некоторые исследователи даже говорят о том, что можно говорить не о чтении текста с экрана, а о его сканировании, просматривании, а это приводит к снижению понимания смысла текста и запоминания его.

Хотелось бы рассмотреть психологические особенности восприятия информации онлайн и оффлайн более подробно.

Информация в интернете идет плотным визуальным потоком, происходит визуализации коммуникации. Но это явление далеко не ново для человека. Ю.В. Кнорозов, в своей работе сказал, что «сочетание изображения и текста характерно для большинства памятников древней цивилизации, как в Америке, так и Старом свете» [2, С. 239]. Рисунок возник гораздо ранее письма и визуальное восприятие для человека более привычно. С развитием 
книгопечатания изображение уходит на второй план, т.е. слово заменяет образ. Но не зря на протяжении многих лет сохраняется поговорка, о том, что лучше один раз увидеть, чем сто раз услышать. Как только возникли технические возможности, визуализация информации возникла достаточно быстро.

Визуальные образы передают некую закодированную информацию, но главное здесь не то, что происходит коллективное взаимодействие воспроизведение существующего смысла образа, а то, что производятся новые смыслы. Это может быть результатом коллективного или индивидуального творчества, но символическое значение они приобретают только в результате социокультурного взаимодействия. Визуальный образ совмещает в себе и однозначность понятий и многозначность, т.е. визуальный образ представляет собой конкретное значение, но в тоже время допускает и вероятность размытость смыслов.

Один и тот же образ, размещенный в различные контексты, может приобретать несхожие, часто противоположные значения. Эта двойственность приводит к дивергентности мышления.

Интерпретация смыслов происходит на основе собственного миропонимания и внутренних ценностей. М.К. Петров визуальную коммуникацию понимает, как фрагмент знания. Этот фрагмент определяет социально значимые виды деятельности, с другой стороны, фрагмент знания является одним из многих таких фрагментов, они давят на него, он оказывает влияние на другие фрагменты из этого и образуется социально значимое знание [3]. Фрагмент знания соединяясь с другими фрагментами образует систему и в этой системе знаний каждый отдельный фрагмент приобретает новое дополнительное для себя значение, которого был бы лишен все данной системы.

В большинстве случаев визуальные образы соединяются с вербальным сообщением и образуются креолизованные тексты. Креолизованный текст - это текст, в котором применяются, как вербальные (языковые) средства, так и не вербальные: символы, рисунки, шрифтовые и цветовые выделения, интервалы. Такие тексты позволяют привлечь внимание, передать как можно больше информации в пределах ограниченного по объему высказывания.

При восприятии человеком одновременно и образа, и текста, текста с иллюстрациями, человек сначала рассматривает «картинку», а затем читает текст. Креолизованные тексты воспринимаются крайне быстро [1]. 
При проведении экспериментов, где испытуемым предлагалось два варианта: первый - запомнить новую информацию с помощью двойного кодирования, т.е. предлагались креолизованные тексты и второй вариант запомнить новую информацию опираясь только на вербальное сообщение. Было выявлено, что двойное кодирование улучшает восприятие информации. Если человек никогда не видел то, что описывается в тексте без визуального образа, то эта информация «проходит мимо» не запоминалась. Картинка придает наполненность, делает узнаваемым понятие.

Реальность оффлайн и реальность онлайн не просто перекликаются, а тесно связаны друг с другом. Изменения в одной реальности влекут изменения в другой, при этом данные изменения оказывают очень сильное влияние на того, кто создает эти трансформации, на человека, который в разных контекстах проявляет свои разные качества. Восприятие визуализированной информации более результативно, чем вербальной информации. Если картинка не соотносится со смыслом текста, то тем больше стремление субъекта интерпретировать образ и через это создается новый бытийный опыт.

В современной действительности человек в короткий временной промежуток переключается между оффлайн и онлайн и это уже создает особую, ранее не существующую повседневность. Визуально организованный мир стимулирует многоплановое восприятие реальности в изменяющихся условиях.

\section{БИБЛИОГРАФИЧЕСКИЙ СПИСОК}

1. Арнхейм Р. Искусство и визуальное восприятие. - М.: Прогресс, 1974. - 392 c.

2. Кнорозов Ю. В. Письменность индейцев майя. - М., Л.: Изд-во АН CCCP, 1963. - 663 c.

3. Петров М. К. Язык, знак, культура. - М.: Наука, 1991. - 328 с. 
DOI

УДК 37.013+316.3

Петряева Татьяна Андреевна, преподаватель, Воронежский государственный лесотехнический университет имени Г.Ф. Морозова

\author{
РОЛЬ БИОГРАФИЧЕСКОГО МЕТОДА В ПРЕОДОЛЕНИИ \\ НЕГАТИВНЫХ ПОСЛЕДСТВИЙ СОЦИАЛИЗАЦИИ ПОДРОСТКОВ \\ В ПРОСТРАНСТВЕ ЦИФРОВОГО ОБЩЕСТВА
}

\title{
THE ROLE OF THE BIOGRAPHICAL METHOD IN OVERCOMING THE NEGATIVE CONSEQUENCES OF THE SOCIALIZATION OF TEENAGERS IN THE DIGITAL SOCIETY
}

\begin{abstract}
Аннотация: В статье подробно рассматриваются социальные изменения, оказывающие воздействие на формирование личности, влияние искусственного интеллекта и СМИ на жизнь современного человека и подростка в процессе социализации, возможные негативные последствия. Автор исследует проблему нравственной деформации у подростков, вызываемой некоторыми особенностями цифрового общества, анализируя при этом положительный опыт использования биографического метода в европейских странах на примере Германии. В статье также описывается эксперимент, проведенный на базах общеобразовательных учреждений города Санкт-Петербург, подводятся его итоги, доказывающие эффективность использования биографического материала в отечественной системе образования.
\end{abstract}

Abstract: The article examines in detail the social changes that affect the formation of personality, the influence of artificial intelligence and the media on the life of a modern person and a teenager in the process of socialization, and possible negative consequences. The author examines the problem of moral deformation in adolescents caused by certain features of the digital society, while analyzing the positive experience of using the biographical method in European countries on the example of Germany. The article also describes an experiment conducted on the bases of general education institutions of the city of St. Petersburg, summarizes its results, proving the effectiveness of the use of biographical material in the domestic education system.

Ключевые слова: биографии известных людей, биографический материал, социализация, нравственное воспитание, цифровое общество, искусственный интеллект

Keywords: biographies of famous people, biographical material, socialization, moral education, digital society, artificial intelligence

(ㄷ Петряева Т.А., 2021 
Сегодня стало совершенно очевидным, что человечество вступило в принципиально новую эпоху своего существования. В обществе происходят столь стремительные, многогранные и взрывообразные изменения, что говорить о возможности какого-либо достоверного социального моделирования теперь уже весьма трудно. Социологическое прогнозирование столкнулось с той же проблемой, что, например, и научный прогноз погоды. Сделать какойлибо относительно долгосрочный прогноз очень сложно ввиду колоссального массива быстро изменяющихся данных. Все это ставит перед человечеством, его научной и политической элитами новые вызовы и вопросы, которые необходимо не просто обсуждать, а и находить на них адекватные ответы и решения, если, конечно, мы хотим выжить как вид homo sapiens.

Социальная действительность за последние десятилетия претерпела существенные изменения буквально во всех сферах жизни общества. Произошел бум научных открытий, которые повлияли не только на развитие фундаментальных знаний, но и до неузнаваемости преобразили повседневную жизнь, сделав ее, с одной стороны, более комфортной, с другой, динамичной и непредсказуемой. Изменения коснулись медицинской сферы, которая вынуждена бороться с агрессивными и ранее неизвестными болезнями, способными повлиять на жизнедеятельность не только отдельного индивида, но и всего человечества. Значительные перемены произошли в экономической сфере, где явно прослеживается стремление к интеграции мирового экономического пространства, созависимости национальных экономик. Однако такой вектор развития мировой экономики устраивает далеко не каждое государство, поэтому наряду с интеграционными процессами наблюдается отстаивание многими государствами своей экономической независимости. Это оказывает влияние на развитие форм экономической деятельности, появление новых площадок для получения прибыли, манеру ведения бизнеса, уровень требований к профессиональным компетенциям персонала. Значительные изменения коснулись информационной сферы. Огромное количество ITтехнологий кардинально изменили повседневную жизнь, предложив, с одной стороны, удобные и энергосберегающие модели решения насущных проблем, с другой стороны, обозначив немалое количество рисков не только правового, экономического, культурного, но и личностного характера. Каждый из этих 
аспектов влияет на деятельность людей, заставляет их приспосабливаться к новым условиям труда.

Современный человек практически с рождения включен в информационное общество. Сегодня вряд ли кто-то способен представить свою жизнь без тех же интернета и смартфона. А ведь еще двадцать-тридцать лет назад все это казалось немыслимым и фантастическим. По словам профессора кафедры психологии, личности факультета психологии Московского государственного университета Галины Солдатовой, на сегодняшний день смартфон - главный инструмент познания мира, средство коммуникации детей и их развития. Такого многофункционального устройства с колоссальными возможностями у подрастающего поколения никогда раньше не было. При этом он настолько прост в функционировании, что даже совсем маленькие дети зачастую становятся его пользователями. Вот уж действительно - нажми на кнопку и получишь результат. Согласно исследованиям, в течение суток в активном распоряжении детей смартфоны находятся в среднем 4,5 часа. Почти каждого четвертого подростка 14-17 лет можно назвать гиперподключенным (23 \% подростков в среднем проводят 9 часов в сутки в интернете) [1, С. 2 ]. Приведенные данные наглядно демонстрируют и, пожалуй, доказывают, что активными потребителями и создателями развитого искусственного интеллекта будут нынешние дети и подростки. Не стоит рассчитывать, что подобная зависимость от гаджетов пройдет в зрелом возрасте, она, это очевидно, только усилится, - современный мир семимильными шагами двигается к информационному, высокотехнологичному и роботизированному миру. Высказанное предположение подтверждается результатами социологического опроса «Динамика пользования интернетом», проведенного Аналитическим Центром Юрия Левады. Полученные статистические данные указывают на то, что в 2019 г. доля совершеннолетних интернет-пользователей превысила 80процентный уровень. Необходимо обратить внимание, что за последние четыре года наиболее заметный рост ежедневных интернет-пользователей отмечается не только среди молодежи, но и старших возрастных групп. Их численность практически удвоилась с 39 \% до 69 \% респондентов в возрасте от 55 лет и старше отмечается троекратное увеличение - с $11 \%$ до $34 \%$ [2, С. 1]. Это совершенно предсказуемая и очевидная ситуация, ведь интернет и его возможности дарят людям не только 
увлекательный досуг, но и оперативное решение повседневных задач (оплата коммунальных услуг, денежные переводы, покупка продуктов и иных вещей, оплата транспорта, управление домашним инвентарем, например, стиральной машиной, кондиционером, роботом-пылесосом т.д.).

В последние десятилетия передовые государства и экономические корпорации стремятся развивать сферу искусственного интеллекта, о чем не раз в своих выступлениях говорили главы государств. Наша страна не отстает от общемировых информационных веяний. Так, например, министр науки и высшего образования РФ Валерий Фальков в одном из интервью обозначил, что в последние годы особую популярность среди молодежи приобретают технические и информационные науки. Сегодня абсолютному большинству понятно, что на первом плане стоят такие направления обучения, как естественные науки (16\%), экономика и менеджмент (16 \%), инженерное дело, технологии и технические науки (15\%) [3, С. 1]. Видится, что значительное влияние на выбор абитуриентов оказывают такие факторы, как цифровизация общества, активное развитие биотехнологий, биоинженерии и кибер-медицины.

Рассуждая над возможностями искусственного интеллекта, лежащего в основе формирования цифрового общества, можно обозначить ряд достоинств и рисков. И если преимущества лежат на поверхности, то риски зачастую одной частью людей не осознаются (по причине недостаточного уровня образования или возрастных особенностей), а другой - просто замалчиваются.

Историк и автор мирового бестселлера «Sapiens: Краткая история человечества» Юваль Ной Харари в своей работе достаточно много размышляет об особенностях работы искусственного интеллекта, его потенциале и дальнейшей судьбе человека в рамках цифрового общества. По мнению Харари, последние достижения в области искусственного интеллекта, в частности, технологии для наблюдения и распознавания лиц могут привести к возникновению оруэлловского общества тотального контроля и сосредоточения власти в руках незначительной группы лиц. Раньше даже в таких тоталитарных государствах, как нацистская Германия или сталинский Советский Союз, режимы не могли все время следить за своими гражданами. Это было весьма желанным, но практически неосуществимым. Однако сейчас мы достигли той степени технического развития, когда новые технологии, сочетающие в себе искусственный интеллект и биотехнологии, биометрические датчики, системы 
навигации, распознавания лиц и голоса, впервые в истории позволяют следить не только за каждым человеком, а и за всеми людьми одновременно. Это может привести к появлению тоталитарных режимов, которые будут намного хуже, чем все, что были в истории до этого времени. И у нас, откровенно говоря, не так уж много времени, чтобы это остановить [4, С. 6] Ключевую роль в сдерживании такого хода событий, конечно же, должны на себя взять страны с развитыми и проверенными на прочность демократиями. Видится, что озвученный социальный риск является не то, чтобы возможным, а и неизбежным. Возникают абсолютно животрепещущие вопросы и вызовы: как сохранить свободу человека, неприкасаемость его личного пространства в ближайшей исторической перспективе (а там, и не за горами, - вообще сохранить себя, как биологический вид), но при этом не отстать в работах по созданию ИИ от государств, ведущих здесь активные исследования и разработки? Как повлиять на ценностные установки людей? Как воспитывать нравственное и, прежде всего, гуманистическое поколение людей? Очевидно, что решение всех этих задач возможно только на глобальном уровне, чтобы буквально каждое государство, каждая элита, политическая, финансовая, научная, была вовлечена в процесс нахождения ответа на возникшие перед нами вызовы. Без консолидации и солидарности эту проблему не решить. Вопрос, ставший перед человечеством, поистине шекспировский: быть или не быть?

Что в этой связи посильно сделать уже сейчас в том же образовательном пространстве? Какие технологии использовать, чтобы минимизировать пагубное воздействие некоторых аспектов современного общества на школьников и студентов, при этом не остановив их позитивного личностного развития? И возможно ли это? Конечно, надо быть реалистами: лишь отчасти. Тот новый контркультурный поток, с которым мы сегодня столкнулись, имеет беспрецедентную идеологическую и финансовую поддержку. И все же...

Думается, что современная школа и в какой-то степени высшие учебные заведения должны взять вектор не столько и не только на достижение предметных результатов, которые в современных реалиях могут оказаться бесполезными в силу высокого темпа развития науки, сколько на формирование моральных основ у обучающихся. Представляется, что для достижения озвученной цели подходит использование биографий известных 
людей, которые помогут тем же подросткам научиться критически анализировать социальную реальность и совершать поступки в поле нравственных, гуманистических ценностей.

Биографии известных людей, как педагогический метод, довольно широко используются в образовательном процессе в европейских странах. Для того чтобы увидеть, как изучение жизни известных общественных деятелей меняет сознание подростков, развивает в них критическое мышление, предлагаем ознакомиться с опытом использования биографического материала на примере такой дисциплины как «Религиоведение», изучаемой в среднем звене в школах современной Германии.

Цель курса заключается в том, чтобы учащиеся могли решать возникающие в их личной жизни ситуации, имея перед собой примеры поступков авторитетных в Германии людей. Открывая тематическую тетрадь, по которой немецкие учащиеся исследуют курс, мы видим оглавление, в котором содержатся имена национальных героев Германии.

Одной из самых значимых фигур в пособии является Пауль Шнайдер. Биографию этой личности учащимся предлагается изучить более углубленно. Ребятам рассказывается о жизненном пути этого немецкого пастора, не принявшего гитлеровской идеологии расизма и нацизма. Ценность этого человека в его личных гуманистических убеждениях, от которых он не отказался даже перед лицом жесточайших пыток и насильственной смерти.

На таких примерах воспитываются подрастающие поколения послевоенной Германии. Они не позволяют себе забывать своих настоящих, истинных героев, включая их в свою собственную жизнь. Они не закрывают глаза на горькую правду, ошибки и даже преступления своего государства. Ведь только через осознание подлинной истории своей страны стало возможным возрождение совершенно иной Германии, где ценности свободы, демократии и достоинства человеческой личности являются национальными, государственными и общественными приоритетами. Именно поэтому современное немецкое образование стремится не только дать багаж теоретических знаний, но и научить своих воспитанников помнить о прошлом, думать о происходящем через призму нравственных ориентиров. Эту задачу немецкие школы реализуют непосредственно через использование биографий известных людей. Во многих школах Берлина существует отдельный предмет, где учащиеся изучают исторические события на основе героических поступков 
своих соотечественников. Особенность изучения данного предмета состоит в том, что учитель позволяет ребятам самостоятельно оценивать поступок человека, рассуждать и приходить к своему мнению, которое подчас бывает неординарным, однако от этого не лишённого нравственного ядра.

Совершенно очевидно, что использование биографического материала в подобном ключе может оказывать существенную роль на воспитание и образование и российских школьников и студентов. Видится, что наиболее эффективным использование биографического метода возможно в процессе изучения уже имеющихся предметов в классах среднего и старшего звена, на первых курсах вузов.

С целью проверки эффективности биографического метода автором был проведен своеобразный научный эксперимент на базе общеобразовательных учреждений. В течение 2017-2018 учебного года среди учащихся параллелей 69 классов ГБОУ гимназии № 114 и ГБОУ СОШ № 605 Выборгского района Санкт-Петербурга были созданы лабораторные и экспериментальные классы. Всем учащимся предлагалась небольшая анонимная работа, в которой были задания на выявление ценностных установок учащихся. Вопросы заданий рассматривали отношения подростков к семейным ценностям, моральной ответственности, любви к Родине, многообразию жизненных позиций и умению находить компромисс в диалоге. По результатам диагностических работ во всех классах проводились уроки на одни и те же темы. В экспериментальных классах (в отличие от контрольных) присутствовал биографический материал, на основе которого изучалась или закреплялась тема урока [5, С. 88-90]. Для сравнения результатов после закрепления материала проводились самостоятельные и творческие работы, которые были нацелены на проверку изменения нравственных ориентиров у учащихся, их гражданских и личностных установок [6, С. 72-73].

Результаты проведенной работы показали, что ценностные установки учащихся экспериментальных классов претерпели значительные изменения в лучшую сторону, поскольку ответы учащихся стали более вдумчивыми и носили оттенок осуждения аморального поведения [6, С. 73].

Подводя итог, хочется сказать, что биографический метод в достаточной степени уникален. Его познавательная и воспитательная роль в социализации школьников и студентов совершенно очевидна [5, С. 326]. Использование в образовательной среде биографий известных людей способствует формированию и закреплению в их сознании гуманистических ценностей. 
Видится, что приоритет именно таких нравственных ориентиров в умах тех, кто завтра станет разработчиком новых технологий, кто будет управлять компаниями и государствами, дает надежду на сохранение свободы человеческой личности, да и вообще нас, как биологического вида, в цифровом обществе.

\section{БИБЛИОГРАФИЧЕСКИЙ СПИСОК}

1. Горячева Ю. Психолог Галина Солдатова: Именно дети и подростки идут в фарватере процесса цифровой трансформации общества // Информационный портал фонда «Русский мир». URL: https://russkiymir.ru/publications/270257 (дата обращения: 18.04.2021).

2. Аналитический Центр Юрия Левады. URL: levada.ru/2019/12/05/dinamika-polzovaniya-internetom/print/ (дата обращения: 18.04.2021).

3. Асатурян Д. М., Спрос на высшее образование со стороны выпускников 11-х классов в 2020 году // Мониторинг экономики образования. 2020. - № 36. - С. 1-7.

4. Синергия: [сайт]. URL: http://Synergy Online Forum: [сайт]. URL: synergyglobal.ru/forums/businessmobilization/2020 (дата обращения: 18.04.2021).

5. Петряева Т. А. Влияние биографий известных людей на формирование нравственных установок у современных школьников // Актуальные вопросы современной наук и образования: сборник статей IV Международной научнопрактической конференции (15 февраля 2021 г.). - Петрозаводск: МЦНП «Новая наука», 2021. - 259 с.

6. Петряева Т. А. Использование биографий известных людей как средство воспитания гражданственности и патриотизма в современном образовательном процессе // Современное образование: опыт прошлого, взгляд в будущее: сборник статей Всероссийской методико-практической конференции (6 декабря 2020 г.). - Петрозаводск: МЦНП «Новая наука», 2020. -268 c. 
DOI

УДК: 37.015.32

Пушкина Тамара Федоровна, кандидат педагогических наук, доцент, Воронежский государственный педагогический университет

Пушкин Александр Сергеевич, студент физико-математического факультета, Воронежский государственный педагогический университет

\title{
РИСКИ ЦИФРОВИЗАЦИИ ОБРАЗОВАНИЯ ШКОЛЬНИКОВ ПОДРОСТКОВОГО ВОЗРАСТА
}

\section{RISKS OF THE DIGITALIZATION OF EDUCATION OF ADOLESCENTS}

\begin{abstract}
Аннотация: В статье рассматриваются проблемы психологической безопасности личности подростка в условиях цифровизации образования. Авторы приводят данные эмпирического исследования школьников по рискам «избыточность информации», «обезличивание» и виртуализация общения.

Abstract: The article examines the problems of psychological safety of a teenager's personality in the context of digitalization of education. The authors cite the data of an empirical study of schoolchildren on the risks of "information redundancy", "depersonalization" and virtualization of communication.
\end{abstract}

Ключевые слова: подросток, психологическая безопасность, личность, риски цифровизации

Key words: teenager, psychological safety, personality, risks of digitalization

Современное образование невозможно представить без цифровых технологий. Благодаря им мы имеем возможность посетить виртуально лучшие библиотеки страны, осуществить виртуальную экскурсию в музеи, заочно путешествовать, учиться, развивать свои интересы, самообразовываться, оперативно получать информацию и многое другое. Но есть и обратная сторона медали, она связана с рисками цифровизации, создающими угрозу психологической безопасности личности. Один из вариантов перевода понятия «гаджет» - «безделушка». Создан он как устройство или приспособление, 
облегчающее и усовершенствующее жизнь человека. Однако при неумеренном пользовании им можно получить неприятные последствия.

Под цифровизацией в настоящее время понимается процесс эксплуатации цифровых технологий во всех сферах жизни общества, в том числе и в образовании. Возникает необходимость развития у всех участников образовательного процесса умений оптимально управлять, понимать, структурировать, интегрировать, обмениваться, рефлексировать, создавать новую информацию и получать доступ к ней с помощью цифровых устройств и сетевых технологий. Все это связано с формированием цифровой культуры человека. В противном случае начинают свое разрушительное действие не учтенные риски цифровизации.

Особенно опасны они для младших подростков при переходе их из начального звена школы в среднее. Подростковый возраст и так называют «трудным» в силу возрастных задач, решаемых в условиях отстаивания своей взрослости в борьбе со взрослыми. Полностью меняется социальная ситуация развития: авторитет взрослого отходит на второй план, более значимы для подростков оценки одноклассников. Ведущей деятельностью, в которой формируются важные личностные новообразования, становится интимноличностное общение со сверстниками, обретение друга, которому можно доверить тайны. Учение перестает быть значимым. Бурно формируется самосознание, за что и сам возраст иногда сравнивают со вторым рождением личности: оценки взрослых подвергаются сомнению, строгой рецензии, а опыт приобретается ценой собственных ошибок и разочарований. Постоянная смена интересов, поиск и проба себя в разных и порой небезопасных увлечениях, может создать угрозу здоровью подростка. Более того все эти сложности сопровождаются тем, что современные пятиклассники выросли в обществе, набирающем темпы цифровизации. Они не понимают, как можно жить без сотового телефона, компьютера, планшета.

В наши дни проблема психологической безопасности личности - предмет пристального внимания ученых. Н.Л. Шлыкова считает, что этот феномен проявляется в адаптивности субъекта, его готовности к принятию решений [6].

T.M. Краснянская личностную безопасность человека связывает с освоением ценностей, развитием нравственности, разумности, ответственности [4]. На наш взгляд, это очень важно для младших подростков, чей жизненный опыт невелик, но переход в более сложное среднее звено школы, 
дистанционный формат обучения, ситуации постоянных изменений в образовании требуют усилий по самосохранению.

Проблемы цифровизации исследуются М.В. Зиннатовой, Е.В. Лебедевой. Среди рисков цифровизации они называют: избыточность информации; «обезличивание» и виртуализацию общения; замещение учебной мотивации игровой вследствие избыточной геймификации; угрозы психологической безопасности и др. [3, С. 36].

М.С. Яницкий считает, что «наиболее важным психологическим аспектом цифрового образования является принципиальное изменение характера коммуникаций субъектов образовательного процесса, определяющее его позитивные и негативные эффекты» [7, С. 38].

Влияние компьютеризации на формирование клипового мышления изучали Л.П. Гурьева, И.В. Завгородняя $[1,2]$.

Анализ источников показал, что данная проблема достаточно хорошо изучена применительно к профессиональному образованию. В то же время выявлено противоречие между необходимостью применения цифровых технологий в образовательном процессе школы и недостаточной цифровой компетентностью их пользователей.

Нами было организовано эмпирическое исследование по выявлению рисков цифровизации образования для психологической безопасности младших подростков. Базой исследования стали несколько общеобразовательных учреждений г. Воронежа и области. Выборку составили 100 обучающихся пятых классов (33 - из г. Воронежа, 34 - из районных центров области, 33 - из сельских школ). Диагностика осуществлялась с помощью авторской анкетыинтервью. Анкетирование проводилось анонимно.

Нас интересовало, как проявляют себя такие риски цифровизации образования, как «избыточность информации», «обезличивание» и виртуализация общения. Анализ полученных нами данных показал следующее.

Риск избыточности информации для подростков анализировался по нескольким показателям. Прежде всего, важно было узнать, сколько времени суток подросток проводит с использованием электронных устройств. Выяснилось, что 40 \% опрошенных работают с гаджетами менее трех часов в сутки, 40\% - около пяти часов, а $20 \%$ - гораздо более пяти часов (в этой группе отмечен рост хорошо успевающих школьников). Процент внушительный для пятиклассников, если учесть, что у них полноценно 
проходят уроки, они выполняют добросовестно домашние задания, дистанционно занимаются с репетиторами, участвуют в дополнительном образовании, заполняют электронные портфолио, посещают электронные библиотеки, то есть все время идет процесс переработки поступающей информации. Общеизвестно, что избыточность информации может вызвать нервно-психическое истощение у человека из-за информационной перегрузки. Ведь приходится обрабатывать огромный поток неструктурированной информации в поисках нужного материала, получается, что цена пятерок для школьника порой велика, поскольку связана с ухудшением здоровья.

Далее в анкете мы просили школьников указать назначение времени, проведенного с использованием гаджетов. Нас интересовало, какую пользу приносят гаджеты, ведь они созданы именно для облегчения и усовершенствования жизни человека; одновременно мы пытались выявить аспекты применения гаджетов в образовательной деятельности пятиклассников. Школьники устанавливали последовательность предпочтений выборов из семи предложенных вариантов. Первые места заняли компьютерные игры и просмотр фильмов (68 \%), подготовка домашних заданий в виде докладов, проектов, презентаций, проверка правильности выполнения заданий с помощью поисковых сайтов (67 \%), общение в соцсетях (64 \%), учебная работа на уроке (44 \%). Можно утверждать, что подростки играют, учатся, отдыхают, общаются, то есть живут, в постоянном сопровождении гаджетов. При этом нельзя сказать, что значительное время они отводят компьютерным играм и просмотрам фильмов. Большую долю занимают учебная деятельность и выполнение домашних заданий, при этом общение в соцсетях также не всегда носит характер свободного, именно в группах одноклассников сверяется правильность выполнения задания, уточняется расписание и т.д. Очевидным результатом является и снижение физической активности, так необходимой подростку для нормального развития.

Анализ рисков, связанных с утратой навыков межличностной коммуникации, проводился по ответам на вопрос: «С кем вы проводите обычно свободное время?» Выбиралось несколько ответов из десяти вариантов. Нас интересовало, находит ли себе место реальное общение в жизни пятиклассников. Партнерами пятиклассников по общению, в основном, стали одноклассники (51\%), родители (44\%), братья и сестры (42\%). «Друзья»в 
социальных сетях оказались менее привлекательными (38 \%), но все же общение с ними занимает значительное место в жизни подростков. Также выяснялось, на основе каких ценностей пятиклассники выбирают себе партнеров по общению. Мы попросили ребят продолжить предложение «Не люблю людей, которые...». Наиболее непривлекательными для общения подростки называют безнравственных (46 \%), агрессивных людей (25\%), эгоистичных (25 \%) и грустных (4 \%). Надо отдать должное учебновоспитательному процессу школ, в которых проходило исследование, подростки в основном ценят реальное общение и выбирают себе партнеров на основе социально-значимых ценностей.

Далее исследованы угрозы безопасности личности, которые связывались нами с возможностью посещения подростками вредоносных сайтов, кибербуллингом, аддикциями и пр. Был задан вопрос: «Считаете ли Вы, что Ваши увлечения гаджетами чрезмерны?». С этим согласились 56 \%. Однако остальные 44 \% уверены, что гаджеты приносят пользу даже при постоянной их эксплуатации. Как видим, подростки уже не представляют своей жизни без этих «безделушек». Нас интересовало, есть ли среди знакомых испытуемых те, поступки которых в Интернет-пространстве могут обеспокоить взрослых: утвердительно ответили - 23\%, но 46 \% были уклончивы, ответив: «Не могу сказать». На вопрос: «Наблюдали ли Вы когда-нибудь в Интернет-пространстве троллинг, кибербуллинг, вредоносный контент?» 63\% опрошенных ответили положительно. Конечно, нас интересовало и время предпочтительного для подростков пользования гаджетами. Выяснилось, что это вечер и день, то есть время, когда ребята в основном находятся в школе или дома, предположительно под присмотром взрослых. Но 18 \%, каждый пятый примерно, пользуется гаджетом ночью, а 14 человек добавили дополнительно к нашему свой ответ: «24×7. Постоянно». На наш взгляд, эта проблема требует корректного обсуждения в педагогических коллективах, на родительских собраниях. Ведь особенно подвержены компьютерной зависимости подростки. Е.Ф. Польшакова обращает внимание на то, что трудные жизненные ситуации подростков, несовершенство «их социальных навыков и личностных ресурсов приводит к уходу от решения проблем, вызванных стрессовыми ситуациями» [5, С. 10]. Нами отмечены 28\% ответов, в которых испытуемые, активно использующие гаджеты, отвечают, что у них нет друзей: «Я один». Свободное время они чаще проводят в одиночестве, играя в компьютер. 
Анализ полученных данных показал, что младшие подростки находятся в зоне риска. Гаджеты сопровождают подростков в учебе, на отдыхе, в общении. При этом большинство испытуемых осознает эту опасность. «Обезличивание» общения, связанное с регрессом навыков межличностной коммуникации, испытуемым пока не грозит, так как их партнерами по общению, в основном, являются одноклассники, родители, братья и сестры. Однако «друзья» в социальных сетях становятся все более предпочтительными для общения. Риск угрозы киберпространства очевиден, поскольку многие испытуемые сталкивались с вредоносными явлениями в виртуальном общении, а время их пребывания в Интернете не всегда контролируется взрослыми. К тому же многие свое одиночество разделяют с компьютером.

Наше исследование показало актуальность работы педагогов по формированию ценностных идеалов у подростков, формированию здорового образа жизни, интенсивной работы по повышению цифровой культуры всех участников образовательного процесса. Мы попытались лишь обозначить некоторые риски цифровизации образования для подростков, но перечень их может быть продолжен.

Актуальной проблемой становится опережение деструктивных влияний цифровизации на личностное развитие школьников подросткового возраста. Ведь цифровизация образования ставит целый ряд задач, направленных на развитие адаптивности личности, ее готовности к принятию взвешенных решений на основе рационального подхода и социально ценных образцов. Психологической основой их решения становится формирование таких качеств личности, как цифровая компетентность, саморегуляция, толерантность, нравственная устойчивость, познавательная активность. При этом одним из важных критериев эффективности будущих и уже действующих цифровых инноваций в образовании является степень сформированности под их влиянием таких психологических новообразований учащихся, которые бы имели отношение к личностной и интеллектуальной зрелости субъекта, его кибергигиене. Важно понимать, что современные цифровые технологии, устройства и приспособления для облегчения жизни человека актуальны прежде всего, как ресурс его саморазвития и заботы о собственной психологической безопасности. 


\section{БИБЛИОГРАФИЧЕСКИЙ СПИСОК}

1. Гурьева Л. П. Психологические последствия компьютеризации: функциональный, онтогенетический и исторический аспекты // Вопросы психологии. - 1993. - № 3. - С. 5-16.

2. Завгородняя И. В. Когнитивные ресурсы студентов как основа и результат педагогической деятельности преподавателя / Современная психология образования: проблемы и перспективы: материалы Всероссийской (с международным участием) науч.-практ. конференции / [под общ. ред. Т. Л. Худяковой]; ВГПУ. - Воронеж: Научная книга, 2016. - С. 144-147.

3. Зиннатова М. В., Лебедева Е. В. К проблеме превенции деструктивного профессионального развития личности в условиях цифровизации // ИНСАЙТ. - 2020. - № 1 (1). - С. 33-44.

4. Краснянская Т. М. Личная безопасность человека в проблемном поле психологии безопасности // Вестник Ставропольского государственного университета. Сер. Педагогические науки. - Пятигорск, 2005. - № 40. - С. 145 153. - Режим доступа: http://vestnik.stavsu.ru/40-2005/19.pdf (дата обращения 18.03.2021).

5. Польшакова Е. Ф. Досуг надо организовывать // Физкультура в школе. - 2002. - № 5. - C. 9-12.

6. Шлыкова Н. Л. Психологическая безопасность субъекта профессиональной деятельности: автореферат диссертации на соискание ученой степени доктора психологических наук. - М., 2004. - 47 с. - Режим доступа: https://dlib.rsl.ru/viewer/01002667493\#?page=1 (дата обращения: 20.03.2021).

7. Яницкий М. С. Психологические аспекты цифрового образования // Профессиональное образование в России и за рубежом. - 2019. - № 2 (34). - С. 38-44. 
DOI

УДК 930.85

Семенова Елена Викторовна, старший преподаватель, Воронежский государственный лесотехнический университет имени Г.Ф. Морозова

\title{
ТРАНСФОРМАЦИИ КОММУНИКАТИВНЫХ ПРОЦЕССОВ В ЦИФРОВУЮ ЭПОХУ
}

\section{TRANSFORMATION OF COMMUNICATIVE PROCESSES IN THE DIGITAL AGE}

\begin{abstract}
Аннотация: Данная статья посвящена истории развития коммуникативных технологий и их изменениям в эпоху цифровизации. В статье приводится периодизация процесса развития массовых коммуникаций и дается характеристика последнего этапа их развития - цифрового.

Abstract: This article is devoted to the history of the development of communication technologies and their changes in the era of digitalization. The article provides a periodization of the process of development of mass communications and provides a description of the last stage of their development - digital.
\end{abstract}

Ключевые слова: информация, коммуникация, самокоммуникация

Key words: information, communication, self-communication

В процессе развития массовой коммуникации канадский культуролог М. Маклюэн предложил выделить три этапа: устный, письменный и электронный [1]. Для устного, дописьменного этапа характерно слияние общающихся субъектов в единое целое, массу. Главными формами передачи информации тогда были сказки, былины, ритуальные тексты, а также новости и сообщения от властных структур. Они передавались из уст в уста, при этом сам слушатель превращался в рассказчика, а рассказчик - в слушателя. Это приводило к искажению информации с каждым новым пересказом в силу индивидуальности каждого рассказчика. Исключение составляли поэтические произведения, которые легко запоминались в первозданном виде, например, «Илиада» и «Одиссея» Гомера. В дописьменную эпоху человек получал 
информацию независимо от своей воли, т.к. звук - всепроникающее явление, достигающее органов чувств. Слова - это образы, тогда как письменность - это символы и знаки. Появление письменности изменило восприятие информации, разделив образ на отдельные символы-единицы. Изменился и процесс передачи информации, в нем появился посредник - материальный носитель информации, рукопись или книга. Теперь человек может уединиться с источником информации и получать ее в первозданном виде, не искаженном пересказами при каждом последующем прочтении. Таким был второй этап развития массовой коммуникации. Третий, по мнению М. Маклюэна, начинается с изобретением электричества, а точнее, радио и телевидения, с появлением СМИ. Во-первых, телевидение восстанавливает баланс органов чувств - зрение и слух снова воссоединяются для приема информации, это благотворно сказывается на человеческой психике. Во-вторых, телевидение связывает общество обратно в единое целое. Мир становится «большой деревней», где события, происходящие во многих километрах от нас, порой имеют не меньшее значение, чем те, которые происходят рядом.

Вместе с тем, важными этапами в предыстории развития современных СМИ отмечают революцию символов в неолите, когда при переходе к оседлости создавались первые корезидентные сообщества, символические действия, объекты и образы активно использовали для объединения и самоидентификации коллективов; а также изобретение печатного станка, что принципиально расширило возможности распространения информации [2]. С появлением и развитием СМИ начинается процесс перехода от индивидуальной передачи информации по горизонтальным каналам к формированию понятия «аудитория», т.е. социальная общность людей, объединенных взаимодействием с источником информации. Газеты, радио, телевидение, также как ритуальные объекты и образы в традиционных культурах, функционируют по модели односторонней, вертикальной коммуникации, где аудитория существует как субъект воздействия. Появление сети Интернет превратило массовую аудиторию в глобальную, при этом вертикальные каналы передачи информации перестали быть односторонними. Зрители, слушатели и читатели получили возможность давать обратную связь и самостоятельно делиться контентом. Добавляются также и горизонтальные каналы передачи информации - между пользователями. 
Вообще-то, Интернет - не новая технология. Впервые она была запущена в 1969 г. под названием Арпанет. Но массовое его использование началось с середины 1990-х гг. в связи с распространением беспроводной коммуникации нового поколения. Если в 1996 г. по всему миру насчитывалось чуть менее 40 млн пользователей Интернета, то к 2013 г. их было уже 2,8 млрд, а на 2021 г. уже 4,66 млрд, что составляет 59,5 \% населения планеты. В абсолютных цифрах по числу пользователей лидируют Китай, Индия, США, Бразилия и на пятом месте - Россия. Коммуникационные технологии все чаще основываются на беспроводных платформах. В 1991 г. насчитывалось около 16 млн абонентов мобильных телефонов (телефонных номеров). В 2013 г. их было уже более 6,4 млрд, в 2018 г. - 7.9 млрд. Это самый быстрый рост коммуникационной технологии в истории. Быстрое распространение Интернета с середины 1990-х годов стало, с одной стороны, результатом технологического открытия Всемирной паутины Тимом Бернерсом-Ли, а с другой - глобальных перемен в культуре и социальном поведении: индивидуализации и осетевления. Массовая коммуникация получила качественно новые свойства, которые некоторые авторы считают современными тенденциями.

1. Глобализация и персонализация. Казалось бы, это противоположные процессы, но в digital-эпоху они развиваются параллельно, усиливая друг друга. Глобализация позволяет СМИ выйти за рамки национальных государств, а приложения для автоматического перевода убирают языковой барьер и делают информацию доступной каждому. При этом глобальная аудитория не однородна, она делится на узкие сегменты по интересам, географии, демографическим характеристикам. Если раньше пользователь сам размещал о себе информацию в интернете, по своему усмотрению выбирая уровень ее доступности, то сейчас машинные алгоритмы анализируют поведение пользователя в сети и определяют его интересы, потребительское поведение и даже географическое местонахождение с точностью до 80\%. Определенное поведение пользователя предоставляет возможность медиа предлагать ему все более подходящий контент, а бизнесу - товары и услуги. Это подводит нас к мысли об усилении роли индивида.

2. Роль индивида возрастает. Потребитель активно вовлекается в процесс коммуникации со СМИ и брендами. Отзывы о товарах и услугах в интернете 
имеют большую степень доверия, чем информация из официальных каналов бренда. Обратная связь активно используется СМИ и брендами для исследования предпочтений индивида и улучшения своего продукта. Интернет позволяет в полной мере реализовывать принцип рыночной экономики выявлять спрос и готовить наиболее востребованное предложение.

3. Личность сама становится СМИ. Первые наскальные рисунки появились благодаря потребности homo sapiens в самовыражении. Сегодня интернет дает практически равные возможности для самовыражения и превращает нас в homomeditates [3]. Блогдает возможность поделиться со всем миром своими мыслями, чувствами или фотографией своего завтрака. Из «сетевого дневника» он превратился в новое средство массовой коммуникации, опережая по уровню доверия и вовлеченности аудитории традиционные СМИ. Известные СМИ, такие как «Ведомости», «Коммерсантъ», почувствовали перемены и вместо того, чтобы соперничать с блогерами, создали для них платформы на своих сайтах. Популярные блогеры начинают сотрудничать с TB. Вот, например, топ-10 самых популярных блогеров России на 2021 г.: Morgenshtern. На его канале сейчас 8 млн подписчиков; Дима Масленников 8,46 млн подписчиков; Wylsacom (Валентин Петухов)- 9,42 млн подписчиков; TheKateClapp (Катя Клэп) - 7,1 млн подписчиков; Анастасия Ивлеева - 4,11 млн подписчиков; Юрий Дудь - самый популярный интервьюер нашей страны - 8 млн подписчиков; Влад А4 - на данный момент самый популярный блогер России и СНГ. Влад снимает челленджи, имеет 23 млн подписчиков. За последний год Влад А4 заработал 80 млн рублей. Практически все они появляются на ТВ, участвуют в различных шоу, а Анастасия Ивлеева даже стала популярной ведущей «Орла и решки». При этом многих исследователей медиакоммуникации волнует проблема размывания понятий интимного и публичного в блоге. По словам М. Кронгауза, блог становится «публичной интимностью», который отвечает эксгибиционистско-вуайеристским наклонностям интернетаудитории [4]. Однако на сегодняшний день эта нарочитая публичная интимность это, скорее всего, просто средство привлечь аудиторию. Блог становится неким подобием сериала, главный герой которого - реальный человек. Таким образом, публичность и интимность сливаются воедино, принимая вид нового феномена цифровой эпохи. 
Еще одна проблема - инволюция способов коммуникации, ее упрощение. Текст утрачивает господствующие позиции в передаче информации, его все больше теснят «эмодзи» и мемы. Интернет-мем - яркая фраза в сочетании с графическим изображением, спонтанно получившая популярность благодаря своей афористичности, ироничности, злободневности. Мем можно отнести к «эпической формуле», то есть языковому клише, используемому для выражения одной и той же мысли. Подобные эпические формулы широко использовались в фольклоре, облегчая понимание и запоминание информации за счет упрощения и схематизации («в тридевятом царстве - в тридесятом государстве», «красна девица», «добрый молодец»). Популярность «эпических формул» через много веков после преобладания устной коммуникации можно объяснить клиповым мышлением и примитивными запросами массовой аудитории. Мем приводит к насаждению стереотипов, однозначному толкованию событий и явлений, а также способствует общей «экономии мышления».

И наконец, важнейшая трансформация интернета, произошедшая уже в XXI в. - создание и распространение социальных сетей. Их популярность говорит о том, что происходит сдвиг от индивидуального взаимодействия с интернетом к общению через социальные сети, контролируемые и управляемые их пользователями. Бурный рост социальных сетей начался с 2002 г. Тогда возникли Friendster, Facebook, YouTube, Twitter, Twenti, QQ, Baidu, Cyworld, BКонтакте, Skyrock, Orkut. «Сайты соцсетей - это сетевые сервисы, которые позволяют индивидам: 1) создавать публичный или частично публичный профиль в рамках фиксированной системы; 2) формировать список пользователей, с которыми они хотели бы установить связь; 3) просматривать свои и чужие списки связей в пределах данной системы и находить в них пересечения» [5]. Сайты социальных сетей становятся платформами для дружеского общения, маркетинга, творчества, образования, развлечения, политической деятельности. Степень открытости и анонимности может контролировать сам пользователь. Это гибридный мир, в котором реальность и виртуальность, открытость и изолированность смешаны в самых разных пропорциях. Это видоизменяет культуру, потому что общение в сети требует небольших эмоциональных затрат, сберегает усилия и энергию. 
Важнейшая трансформация в коммуникационной сфере за последние годы - это сдвиг от массовой коммуникации к массовой самокоммуникации, понимаемой как процесс интерактивной коммуникации, потенциально доступной для массовой аудитории, но в рамках которой производство сообщений осуществляется пользователем самостоятельно, как и обратный возврат сообщений, а восприятие и реструктурирование контента, полученного из электронных коммуникационных сетей, - произвольно.

\section{БИБЛИОГРАФИЧЕСКИЙ СПИСОК}

1. Архангельская И.Б. Маршалл Маклюэн. - Н. Новгород: НКИ, 2010. $-291 \mathrm{c}$.

2. Корниенко Т.В. Концепция «революции символов» Жака Ковена двадцать лет спустя // Вестник Воронежского государственного университета. Серия: История. Политология. Социология. - 2015. - № 1. - С. 82-86.

3. Мансурова В.Д. «Медийный» человек как проекция дигитальной онтологии // Известия Алтайского государственного университета. - 2010. № 2-2 (66). - С. 116-120.

4. Вокуев Н.Е. Между дневником и масс-медиа: особенности блога как средства коммуникации // Электронное научное издание «Аналитика культурологии». - 2011. - № 1(19). - URL: http://analiculturolog.ru/journal/ archive/item/675-between-diaries-and-media-especially-blog-as-a-communicationtool.html (датаобращения: 28.03.2018).

5. Розенберг Н.В., Сараева В.П. Массовая коммуникация: основные тенденции развития в эпоху digital // Электронный научный журнал «Наука. Общество. Государство». - 2018. - T. 6. - № 2 (22). - URL: http://esj.pnzgu.ru ISSN 2307-9525 (датаобращения: Online). 


\section{DOI}

\section{УДК 159.9:316.6}

Трегубова Анна Сергеевна, студент лесного факультета, Воронежский государственный лесотехнический университет имени Г.Ф. Морозова

\section{КИБЕРБУЛЛИНГ В ПОДРОСТКОВОЙ СРЕДЕ}

\section{CYBERBULLYING IN THE TEENAGE ENVIRONMENT}

Аннотация: В современном мире, где, благодаря техническим достижениям, насилие выходит на новый уровень, появились новые способы оскорбления, унижения и травли. В данной работе рассматривается одна из главных угроз, с которой могут столкнуться подростки в интернет-пространстве - «кибербуллинг»; представлены история его появления, возможные меры противодействия и профилактики.

Abstract: In the modern world, where technological advances are taking violence to a new level, new ways of offending, humiliating, and harassing have emerged. This article examines one of the main threats that teenagers may face in the Internet space- "cyberbullying": the history of its appearance, the methodology of research, possible measures to counteract and prevent it.

Ключевые слова: кибербуллинг, троллинг, интернет-травля, подростки

Keywords: cyberbullying, trolling, Internet bullying, teenagers

Глобальное развитие цифрового пространства не только предоставляет доступ к большому количеству информации, обеспечивает огромный потенциал для развития многих сфер деятельности, но и способствует возникновению новых форм негативного воздействия на людей, посредством чего в цифровом пространстве появилось такое социальное явление как кибербуллинг. Кибербуллинг (интернет-травля унижением) - это осознанное, продолжительное причинение психологического давления на человека в виде коллективных травли, оскорблений и/или угроз в течение продолжительного времени. Чаще всего от кибербуллинга страдают подростки.

Проблема буллинга стала объектом исследований ещё в 1905 г., когда ей занялся английский психолог К. Дьюкс. В российской науке этом явлением занимались И.С. Кон, С.Н. Ениколопов, В.С. Собкин, С.В. Кривцова, 
А.А. Белевич, А.Н. Шапкина и др. Однако его современная разновидность является самым молодым видом «запугивания» и берёт своё начало примерно в 2000-х годах, когда информационные технологии стали активно входить в массы и приобретать повсеместный характер. Сейчас данное явление не перестаёт исследоваться, появляется всё больше работ отечественных и зарубежных учёных. Так, разнообразным психологическим манипуляциям в сети уделила внимание А.О. Андреева [1], психологические причины формирования и распространения подросткового кибербуллинга рассматривает творческий тандем А.А. Баранова и С.В. Рожиной [2], с феноменологических позиций это явление исследует О.С. Черкасенко [3].

В данной проблематике на современном этапе наиболее важной является эмпирическая сторона исследования, именно благодаря сбору информации с помощью опросов и тестирования можно представить наглядную картину происходящих явлений в обществе. Собранные статистические данные систематизируются, что позволяет перейти к теоретическим выводам и анализу причинно-следственных обстоятельств.

Важные статистические исследования проводятся за рубежом. Так, американская компания McAfee, входящая в состав Intel Security, представила информативные выводы своего исследования «Подростки за компьютером2014: вопросы защиты личной информации, общения в социальных сетях и кибербуллинга». Объектом ежегодных исследований этой компании на протяжении уже длительного времени является динамика изменений поведения в виртуальном пространстве и особенности сетевого общения детей подросткового возраста. В свою очередь, консалтинговая фирма The Futures Company в апреле 2014 г. провела устный опрос среди полутора тысяч американских молодых людей и девушек в возрасте от 10 до 18 лет, который выявил резкий скачок по одному из важных показателей. Так, если в 2013 г. только 27\% подростков стали свидетелями кибербуллинга, то в 2013 г. - уже $87 \%$. Среди тех, кто признался в том, что сам стал объектом виртуальной травли, $72 \%$ в качестве причины назвали свою внешность, $26 \%$ национальность или вероисповедание и $12 \%$ заявили, что решающим фактором послужила половая сфера [4].

Особенность кибербуллинга в том, что данный вид травли очень сложно контролировать, так как злоумышленник имеет возможность использовать 
псевдоним: в личном профиле практически каждой социальной сети можно указать «фейковые» данные и совершенно любую информацию, следовательно, остаться инкогнито.

Таким образом, осуществлять травлю в сети значительно проще. Возможно, в реальной жизни потенциальный обидчик чувствует соблазн оскорбить или унизить другого человека, однако остерегается, что его осудят или даже привлекут к ответственности. Но в социальной сети перед человеком стираются коммуникативные границы. Отчасти ресурс сетевого общения подталкивает людей, имеющих в этом потребность, но боящихся ответственности, совершать троллинг с помощью мессенджеров и других форм онлайн-общения. Но здесь стоит отметить, что всё же очень часто кибербуллинг является продолжением буллинга из реальной среды социального мира.

Характерным качеством кибербуллинга являются его безграничные, «вирусные» способности в сети. Интернет-травля способна вовлекать в себя широкую аудиторию. Порой, чтобы наткнуться на травлю в сети, достаточно совершить пару кликов, и вот он обидный комментарий под фото или оскорбительный пост, посвящённый подростку. Так как свидетелем и участником может стать кто угодно, жертве будет казаться, что о проблеме знают абсолютно все. Таким образом, кибербуллинг будет причинять больше страданий, нежели личное оскорбление, имеющее ограниченное количество свидетелей. При этом стоит помнить, что написанное в Сети останется там навсегда.

Помимо этого, находясь на дистанции, обидчик не всегда способен оценить причиняемый вред, ведь он не видит, как жертва реагирует на его действия, другими словами, благодаря возникающей дистанции между хулиганом и жертвой притупляется эмпатия - состояние сопереживания относительно другого человека. Это значит, что боль человеку можно причинить, даже не осознавая этого, а само насилие, вообще, может не иметь границ.

При этом, когда жертва становится объектом коллективной, спланированной, регулярной агрессии, она невольно задумывается о её причинах, в результате чего появляется боязнь встречи с обидчиками, социофобия в реальной жизни, мысли, как её избежать. Рождается страх, 
который мешает сосредоточиться на повседневных вещах, формируется тревожное, стрессовое состояние. Кибербуллинг несёт за собой реальную угрозу, он заставляет человека страдать целыми днями!

Анализируя социальные сети, можно выделить несколько разновидностей проявления кибербуллинга:

- оскорбительные и обидные комментарии;

- публикация фото-видеофайлов, содержащих оскорбляющий материал;

- создание чужого профиля в социальной сети с целью выполнения действий от чужого имени;

- распространение ложной информации с помощью мессенжеров и других форм онлайн-общения;

- угрозы, проявление ненависти, унижения, распространяемые благодаря ресурсам цифрового пространства.

По мнению исследователей А.А. Барановой и С.В. Рожиной, спектр психологических причин, порождающих кибербуллинг очень многообразен. А в числе самых распространенных они называют: стремление к превосходству, субъективное чувство (комплекс) неполноценности, зависть, месть, развлечение, конформизм, проблемы в семейных взаимоотношениях, низкий уровень развития эмпатии, отсутствие умения разрешать конфликты, индивидуально-личностные характеристики индивида (акцентуации характера, проблемы в эмоционально-волевой сфере и др.) [2].

Интернет-пространство явилось ярким феноменом в современной жизни мирового сообщества, оно затрагивает все сферы общества: экономическую, социальную, политическую и духовную. Цифровое пространство пришло в жизнь людей в конце XX - начале XXI вв. в качестве новой сферы бытия. Можно сказать, что Интернет становится новым социальным институтом. И продолжает формироваться благодаря своим пользователям, в том числе, или даже в бо́льшей степени, молодёжью. Именно от нас зависит каким он будет через десятки лет. Перед нами лежит важная задача построить интернетпространство комфортным и безопасным. В том числе, возвращаясь к теме кибербуллинга, найти пути решения этой важной проблемы, создающей угрозу безопасного пользования сети, создать нужные условия для детей и подростков.

Необходимо разрабатывать и внедрять множество вариантов борьбы с кибербуллингом, начиная с его профилактики. Например, с привлечением школы, чтобы ещё на этапе формирования личности педагоги могли 
минимизировать данное явление, научить детей решать конфликты, не применяя насилия. Проводить беседы с учениками на тему буллинга (кибербуллинга) в рамках учебного плана, рекомендовать соответствующую литературу, информировать о существовании телефона доверия для детей и подростков, где работают квалифицированные психологи, готовые оказать помощь, привлекать к этому родителей.

Помимо того, в России действует федеральный закон от 29 декабря 2010 г. № 436-Ф3 «О защите детей от информации, причиняющей вред их здоровью и развитию». Закон запрещает распространение нежелательной информации среди детей в зависимости от их возраста. С 1 сентября 2012 г. вся информация стала маркироваться соответствующими отметками возрастной категории (0+, $6+, 12+, 16+, 18+$ ) [5]. Однако такая маркировка не даёт полных гарантий информационной безопасности детей в интернете.

По нашему мнению, важную роль в профилактике и пресечение кибербуллинга может сыграть абсолютно каждый неравнодушный пользователь Сети. Помимо простого и очевидного информирования о прецедентах травли, предания общественной огласке встречающиеся случаи, профилактика и борьба с буллингом в Сети может вестись следующими способами:

1) Пропаганда обратного. В ответ на оскорбление за жертву можно заступиться, и если можно так выразиться, аннулировать злое послание, оставив доброжелательный комментарий, тем самым дать понять, что подросток не одинок и может рассчитывать на поддержку со стороны окружающих.

2) Организация флешмобов. Хороший способ привлечь внимание к проблеме - организовать флешмоб. Эта идея очень яркая, и она вряд ли останется без внимания аудитории. Примером такой акции является флешмоб в Канаде, где в день борьбы с буллингом школьники устроили танец в торговом центре, распространив тем самым важную идею, что травля несёт за собой серьёзную опасность, а значит требует особого внимания.

3) Написать поучительный рассказ, комикс. Важно рассматривать проблему с понятной и доступной для детей и подростков точки зрения. Давая понять ещё в малом возрасте, что кибербуллинг недопустим и опасен.

4) Ведение блога в социальных сетях. Иногда люди, попавшие в сложную ситуацию, начинают говорить о ней с целью помочь таким же 
жертвам, как и они сами, это можно сделать благодаря ведению блога в тех же социальных сетях. Там можно оказывать поддержку и помогать выйти из ситуации давая советы и делясь собственной историей борьбы с буллингом.

5) Создание целого движения. Сейчас всё чаще стали придавать огласке важные социальные проблемы. Чем большей аудитории будет известна та или иная проблема, тем больше шансов, что ей заинтересуются люди, готовые и способные изменить ситуацию.

По результатам данного исследования, можно сделать следующий вывод. В настоящее время кибербуллинг активно развивается и мимикрирует, это явление ещё малоизучено, и ему ещё предстоит пройти множество исследований. Такой феномен не может остаться без должного внимания. Ведь важной социальной задачей является создание безопасного цифрового пространства для развития, образования и коммуникации пользователей Интернета. Необходимо искать и принимать меры для предотвращения данной проблемы, которые помогут подростку не стать жертвой кибербуллинга.

\section{БИБЛИОГРАФИЧЕСКИЙ СПИСОК}

1. Андреева А. О. Манипулирование в сети Интернет // Информационная безопасность и вопросы профилактики киберэкстремизма среди молодежи. Мат. конф. / под ред. Г.Н. Чусавитиной и др. - Магнитогорск, 2015. - С. 21-28.

2. Баранов А. А., Рожина С. В. Психологический анализ причин подросткового кибербуллинга // Вестник Удмуртского университета. - 2015. № 3. - С. 37-41.

3. Черкасенко О. С. Социальная сеть как разновидность социальной коммуникации // Материалы 36 международной конференции: Вопросы педагогики и психологии. Сб. ст. - 2015. - № 3. - С. 141.

4. McAfee: исследование «Подростки за компьютером-2014: вопросы защиты личной информации, общения в социальных сетях и кибербуллинга // Технологии в образовании: новости и события. URL: http://educationevents.ru (дата обращения: 09.04.2021)

5. Как обеспечить безопасность детей в интернете // Безопасность детей в интернете - правила безопасности в сети интернет. URL: https://externat.foxford.ru/polezno-znat/bezopasnost-detej-v-internete (дата обращения: 26.01.2021). 
DOI

УДК 172

Чаплыгин Андрей Владимирович, кандидат физико-математических наук, доцент, Международный институт компьютерных технологий

Попова Марина Анатольевна, кандидат политических наук, доцент, Международный институт компьютерных технологий

\author{
ЦИФРОВОЕ ОБЩЕСТВО КАК РЕЗУЛЬТАТ РАЗВИТИЯ \\ ИНФОРМАЦИОННЫХ ТЕХНОЛОГИЙ: К ИСТОРИИ ВОПРОСА
}

\title{
DIGITAL SOCIETY AS A RESULT OF DEVELOPMENT OF INFORMATION TECHNOLOGIES: TO THE HISTORY OF THE ISSUE
}

\begin{abstract}
Аннотация: В данной статье рассматриваются особенности и возможности информационного общества, основанные на производстве и продаже качественно новых технологий, позволивших современной цивилизации создать ещё более совершенный электронно-цифровой способ хранения и распространения информации.

Abstract: This article examines the features and capabilities of the information society based on the production and sale of qualitatively new technologies that have allowed modern civilization to create an even more advanced electronic-digital way of storing and disseminating information.
\end{abstract}

Ключевые слова: информационное общество, цифровое общество, виртуальная реальность, информациональный способ, технотронное общество

Key words: information society, digital society, virtual reality, informational method, technotronic society

На рубеже XX-XXI вв. все цивилизованные государства рассматривали построение информационного пространства как основу для своего социальноэкономического, политического и культурного развития, что, в свою очередь, привело к расцвету инновационных технологий и переходу к цифровому обществу. Если спецификой информационного общества является изменившаяся роль информации в материальной и духовной сферах, то 
ключевой характеристикой цифрового общества становится не сама информация, а электронно-цифровой способ ее хранения и распространения, проникающий во все аспекты социальных отношений.

Рассмотрим историю зарождения современного цифрового общества, опираясь на социологические исследования информационной цивилизации. В начале 60-х гг. XX в. был введён термин «информационное общество», определяющими характеристиками которого должны были стать производство и продажа качественно новых технологий во всех сферах, позволяющих обществу жить и развиваться не за счёт сырьевых ресурсов, а за счёт реализации технологических идей.

Интерес представляет теория американского социолога Э. Тоффлера, в которой были сформулированы основные принципы «кода» «третьей волны», как он определил информационное общество, противопоставляя их принципам индустриальной цивилизации («второй волны»).

Эти принципы, по мнению Э. Тоффлера, следующие: дестандартизация, деспециализация, десинхронизация, деконцентрация, демаксимизация, децентрализация. Они характерны для техносферы, социосферы и инфосферы, то есть системы производства и распределения информации. Информационное общество опирается на новые институты, отношения, ценности, основанные на разнообразных возобновляемых источниках энергии; на методах производства, отрицающих большинство фабричных сборочных конвейеров; на новой структуре, которую исследователь называет «электронным коттеджем»; на радикально измененных школах и объединениях будущего [4, С. 280].

Инфосфера третьей волны создает новую интеллектуальную среду благодаря быстрому распространению компьютерного интеллекта. Это несет с собой определенные опасности, но исследователь оптимистично считает, что «у нас есть интеллект и воображение, которыми мы до сих пор не начали пользоваться», компьютеры «помогут нам гораздо серьезнее думать о самих себе и о мире, в котором мы живем» [3, С. 286].

В то же время, нельзя забывать о негативных сторонах всеобщей компьютеризации, часто выключающей человека из реальности, заменяющей её виртуальным миром. Некоторые исследователи считают виртуальную реальность новой сферой бытия, а информационное пространство - формой существования виртуальной реальности, которая с помощью современных 
операционных средств мультимедиа создает иллюзию непосредственного присутствия в «экранном» мире.

Виртуальная реальность является синтезом техники и человеческого воображения, её воздействие на психику человека и культуру человеческого общества в целом трудно переоценить. К сожалению, это воздействие не всегда положительно.

Виртуальный характер общения коренным образом меняет положение человека в социуме и значительно трансформирует его сознание. Открытый информационный взаимообмен позволяет каждому представителю социума воспринимать новые ценности, активизировать своё личностное начало, самоопределиться. Однако новый тип компьютерного поведения личности не гарантирует развитие духовного мира самого человека, возникает угроза потери индивидуальности, чего, по мнению Э. Тоффлера, не должно произойти. Он предполагал, что демассифицированные средства информации ускорят движение общества к разнообразию, люди станут более индивидуализированными.

Под воздействием всех информационных технологий общество постепенно превращается в потребителя «картинок» и «иллюстраций», а культура интерпретации и понимания письменных текстов снижается, возникает глобальная проблема обучения, так как только книга учит думать.

Испанский социолог M. Кастельс ввел новый термин «информациональный» - для обозначения современного способа общественного развития. Исследователь отмечает, что в результате информационно-технологической революции и глобализации создана особая социальная организация, в которой операции с информацией становятся базовыми источниками производительности и власти.

«В новом, информациональном способе развития источник производительности заключается в технологии генерирования знаний, обработки информации и символической коммуникации. Разумеется, знания и информация являются критически важными элементами во всех способах развития, так как процесс производства всегда основан на некотором уровне знаний и на обработке информации. Однако специфическим для информационального способа развития является воздействие знания на само знание как главный источник производительности...» [2, С. 35]. 
Другой ключевой чертой информационального общества является его сетевая структура, заменяющая прежние иерархии: «Не все социальные измерения и институты следуют логике сетевого общества, подобно тому, как индустриальные общества в течение долгого времени включали многочисленные доиндустриальные формы человеческого существования. Но все общества информационной эпохи действительно пронизаны - с различной интенсивностью - повсеместной логикой сетевого общества, чья динамичная экспансия постепенно абсорбирует и подчиняет предсуществовавшие социальные формы».

Особый вклад в развитие идеи информационного общества внес американский политолог и социолог 3. Бжезинский, разработавший концепцию технотронного общества, которое в культурном, психологическом, социальном и экономическом отношениях формируется под воздействием техники и электроники, особенно развитой в области компьютеров и коммуникаций.

Вызванные ими изменения чрезвычайно содействуют связанности общества, члены которого пребывают в непрерывных и тесных слуховизуальных контактах, постоянно взаимодействуя, соучаствуя в наиболее напряженных социальных испытаниях, и их легко можно подтолкнуть к усилению личного подключения к решению даже весьма отдаленных проблем. Новое поколение не занимается более определением мира, опираясь исключительно на чтение; оно испытывает мир и ощущает его компенсаторно с помощью слуховизуальных коммуникаций [1, С. 29].

Технотронная революция позволяет в кратчайшие сроки экспортировать стереотипы поведения и образ жизни на новые территории, что приводит к потере национальных и локальных особенностей, к разрушению традиционных связей в современном обществе, которое выходит на глобальный уровень.

«Влияние науки и техники на человека и его общество стало (особенно в более развитых странах мира) главным источником современных изменений. Трансформация, которая ныне имеет место, особенно в Америке, уже создает общество, которое все более отличается от своего индустриального предшественника. В технотронном обществе научное и техническое знание, в дополнение к обогащению производственных способностей, быстро оплодотворяет почти все аспекты жизни, прямо воздействуя на них» [1, С. 20]. 
В целом концепция технотронного общества, разработанная 3. Бжезинским, опиралась на принципы и идеалы, которые мыслились как несовместимые с индустриальным прошлым. Так, в производственной сфере автоматизация и новая кибернетическая техника заменят операции человека с машинами, в социальной сфере произойдет перемещение центра тяжести от проблем материального благосостояния (ибо они будут решены) к проблемам духовным, а человек станет активным членом социума.

Таким образом, концепции информационного общества отличались технологическим детерминизмом, акцентировали внимание на приоритете технико-экономических, информационно-коммуникационных структур в социальном прогрессе общества, вытесняющих классово-антагонистические отношения и создающих возможность для взаимообмена культур.

Современный исторический этап характеризуется формированием цифровой культуры, основанной на достижениях информационного общества, влекущей за собой изменения социальных отношений в целом и трансформацию идентичности человека в частности. Цифровые коммуникации быстро меняют мир, предоставляя человечеству принципиально новые возможности развития.

\section{БИБЛИОГРАФИЧЕСКИЙ СПИСОК}

1. Бжезинский 3. Между двумя веками: роль Америки в эру технотроники / Перевод с англ. И. М. Максимовой. - М.: Прогресс, 1972. - 308 с.

2. Кастельс М. Информационная эпоха. Экономика, общество и культура / Перевод с англ. под науч. ред. проф. О. И. Шкаратана. - М.: ГУ ВШЭ, 2000. $590 \mathrm{c}$.

3. Тоффлер Э. Раса, власть и культура // Новая технократическая волна на Западе: Сб. статей. - М.: Прогресс, 1986. - С. 276-288.

4. Тоффлер Э. Третья волна. - М.: ООО «Фирма «Издательство АСТ», 1999. $-784 \mathrm{c}$. 
DOI

УДК 378

Чучупал Вячеслав Васильевич, старший преподаватель, Воронежский государственный лесотехнический университет имени Г.Ф. Морозова

\author{
ЦИФРОВИЗАЦИЯ ГУМАНИТАРНЫХ ДИСЦИПЛИН \\ В ТЕХНИЧЕСКОМ ВУЗЕ: ТРУДНОСТИ И ПЕРСПЕКТИВЫ
}

\title{
DIGITALIZATION OF HUMANITARIAN DISCIPLINES IN A TECHNICAL UNIVERSITY: DIFFICULTIES AND PROSPECTS
}

\begin{abstract}
Аннотация: Рассматриваются вопросы использования современных информационных технологий в учебном процессе высшей школы. Анализируются трудности, с которыми сталкиваются преподаватели гуманитарных дисциплин, указываются оптимальные пути преодоления этих препятствий и синтеза аналогового и цифрового формата обучения.
\end{abstract}

Abstract: The article deals with the use of modern information technologies in the educational process of higher education. The article analyzes the difficulties faced by teachers of humanities, indicates the most optimal ways to overcome these difficulties and the synthesis of analog and digital learning formats.

Ключевые слова: информационные технологии, дистанционное обучение, индивидуальный подход, цифровизация, гуманитарные науки, образ будущего

Keywords: information technologies, distance learning, individual approach, digitalization, humanities, image of the future

Процессы цифровизации широко затронули всю сферу высшего образования - организационную, финансовую, содержательную. С содержательной точки зрения они предполагают применение студентами и преподавателями мобильных интернет-технологий, расширяющих горизонты познания и открывающих новые возможности: обучение в любое удобное время, непрерывное образование, способность проектировать индивидуальные образовательные маршруты. Переход на дистанционный формат занятий, происшедший в последнее время как вынужденная мера, наглядно 
продемонстрировал необходимость цифровизации учебного процесса для его стабильности в любых условиях. Цифровые технологии формируют у студентов компетенции XXI в.

Очевидно, что образование во всём мире уже не будет прежним. Вопрос лишь в том, в каком направлении следует развивать цифровизацию обучения в вузах, каковы ближайшие цели и задачи учебных заведений в этой сфере. Очевидно, что эти цели являются общими для всех вузов. Но в каждом из них имеется и своя специфика, затрудняющая или, напротив, облегчающая их достижение. Так для вузов инженерно-технического профиля важны, прежде всего, профильные учебные дисциплины, которые непосредственно формируют у студентов необходимые для их специальности профессиональные компетенции. Потребность в тщательном освоении этих дисциплин очевидна и в плане цифровизации здесь необходимы методические инновации, перестройка непосредственно учебного процесса и оптимизация профессиональной подготовки.

В особом положении оказываются кафедры гуманитарных дисциплин в технических вузах. Их положение вообще является довольно сложным. Толькотолько отшумели страсти, связанные с переходом от специалитета к подготовке бакалавров и магистров. Из этой реформы кафедры гуманитарного профиля вышли потрепанными и ослабленными. При общем сокращении учебной нагрузки деканаты и выпускающие кафедры отыграли, прежде всего, в пользу профилирующих дисциплин, урезав учебные часы на предметы, которые не являются профильными для будущих выпускников технических вузов. Обычным делом стало слияние гуманитарных кафедр: отдельные кафедры философии, истории и политологии превратились в одну-единственную кафедру социально-гуманитарных наук. Но даже на такую единственную кафедру зачастую не хватает учебных часов. По этой причине уполовинен по сравнению с лучшими временами их преподавательский состав и процесс его «усыхания» продолжается.

Никуда не делся, а, наоборот, стал еще более актуальным и застарелый вопрос о том, зачем вообще нужны гуманитарные предметы в техническом вузе? Для чего будущему инженеру история, социология, философия и прочие социальные науки? Какие конкретные профессиональные компетенции они дают и как помогут выпускникам быть конкурентноспособными на рынке 
труда? Этот вопрос как древнегреческий Сфинкс говорит обществоведу: «Реши эту загадку, или погибнешь в моих когтистых лапах!». Печальный парадокс состоит в том, что преподавателю гуманитарных дисциплин трудно ответить на этот вопрос с исчерпывающей ясностью. Как формировать личность вообще, если нет социального заказа на формирование той личности, которая нужна будущей России? Сегодня нет четкого образа этого самого будущего. В социуме лишь начинается некое осмысление стратегических целей развития, и соответственно поиски ответов на вопросы: «кого учить», «чему учить», «что изучать», «для чего учить». Какие кадры потребны обществу на нынешнем этапе его исторического развития и т.д. В целом же будущее России туманно, находясь между великим прошлым и неопределенным будущим, страна переживает период безвременья.

Говорят, например, что весь западный мир нам враг, а кто тогда друг? Китай? Или рассуждения о том, в России будет госкапитализм с цифровым лицом, но какой образ будущего власть может предложить нашей молодежи? Похоже, что эта картинка близка к замятинскому «Мы» или оруэловской утопии. Если гуманитарные науки ещё не удалены окончательно из учебных программ, то какую роль они должны играть? Что достанется гуманитариям в процессе перехода на цифровой формат обучения. Выйдут ли обществоведческие кафедры из этого испытания окрепшими или же будут оттеснены на задворки учебного процесса. Вопросы можно множить и множить.

Безусловно, это вызов гуманитарному образованию и на него надо найти достойный ответ. Над этими мировоззренческими вопросами предстоит еще долго и напряженно думать. В целом же цифровизация нужна для вузовских обществоведов по той же причине, что и для профилирующих кафедр. Она преобразует социальную парадигму учебного процесса, открывает возможности получения и совершенствования знаний, расширения кругозора. Для студентов отпадает необходимость сидеть в вузовской аудитории, воочию общаться с преподавателем, рыскать по библиотекам в поисках учебника. Учебный процесс, становится более гибким и «заточенным» под конкретного студента. Обучающиеся сами формируют запрос на получение знаний, и включается в процесс обучения в удобное для них время. Это позволяет давать всем одни и те же знания, но с учетом локального элемента. 
Как известно, у студентов разные запросы, подходы и карьерные ожидания. Так преодолевается конфликт между тем, что всех надо учить чемуто общему, но при этом делать так, чтобы оно соответствовало желаниям, способностям и ожиданиям отдельных студентов. Персонализация и практическая обучения обусловлена, с одной стороны, тем, что всё больше различаются образовательные потребностей молодых людей, различием их мотивации и когнитивных способностей, а с другой стороны - теми широкими возможностями, которые открываются для такой индивидуализации.

Принято считать, что все недостатки, это продолжение наших достоинств. И здесь кроются главные риски и трудности. Главный недостаток цифрового образования состоит в том, что студент лишается личностного общения, что называется глаза в глаза. Это нарушение социализации, сужение кругозора восприятия, при которых становится возможным формирования человека «одной кнопки», натасканного на узкие навыки и встроенного в систему электронного управления. Это особенно нежелательно в гуманитарной сфере, где ничто не заменит живого общения.

В ответ на такие опасения сторонники цифровизации говорят о том, что изменилась сама аудитория и преподавателю volens nolens придется меняться вслед за ней. Прежнего студента нет! Есть некие «цифророжденные». Эти представители нового поколения «устроены» совершенно по-другому, они, возможно, впервые действительно другие за всю историю человечества. И поэтому не могут воспринимать информацию так, как еe воспринимали предшественники. Например, выслушивать классические полуторачасовые лекции даже самого квалифицированного преподавателя. Зато могут переварить огромный объем информации, но частями и по запросу.

При цифровизации, скажем, курса «Истории Отечества» преподавателя подстерегают две опасности, это, во-первых, чрезмерная схематизация, и вовторых - такая же чрезмерная визуализация.

Если говорить о первом, то многие преподаватели прибегают на лекциях к схемам, которые проецируются на экран. В этих схемах по пунктам перечислены все важнейшие положения темы, и в ходе лекции преподаватель лишь комментирует эти положения. Живая связанная, образная речь лектора отходит на второй план. Он не читает лекцию, а как бы растолковывает все те пункты, которые вынесены им на экран. Хорошо это или плохо? Трудно 
сказать! С одной стороны, студенту не надо выбирать из лекции главное, анализировать сказанное, все это уже сделано за него, ему остается усвоить даже не всю тему, а лишь готовый опорный или как его еще можно назвать эвристический конспект. Казалось это нормально - знания представлены в готовом, препарированном виде и сами лезут в голову студента. Более того, если интерактивная доска подключена к студенческим планшетам, то не надо ничего списывать, информация сама, без всякого усилия с их стороны перетекает к слушателям. Но здесь схема, а не живая мысль лектора начинает руководить всем познавательным процессом. Исторический процесс лишается живых красок, остается лишь выморочная канва событий. Слушатели теряют способность непрерывно воспринимать сообщаемый учебный материал, выделять в нем главные места. Студенты не погружаются в смысл рассказанного лектором, а в итоге истинного понимания нет, и в памяти ничего не задерживается.

Вообще, при цифровых технологиях и интернета их восприятие информации постепенно становится всё более и более поверхностным. Раныше при подготовке реферата по той или иной теме студенты читали книги, вникали в изучаемый вопрос, а теперь путешествуют по Интернету, бегло читают и копируют, не задумываясь о том, что они скопировали себе в реферат. Бывают и такие анекдотические случаи, что студент читает свой реферат, а на вопрос пояснить, что он имел в виду в своем тексте, бесхитростно отвечает: «Не знаю!». Все перекопировано им чисто механически. Замещение цифровыми технологиями естественной передачи знаний от старшего поколения младшему неизбежно приведёт к утрате навыков самостоятельного мышления.

Сложным является и вопрос обратной связи при дистанционном обучении. Замена экзамена или зачета высылаемыми студентам тестами ставит вопрос о том, как проконтролировать этот процесс, убедиться, что обучаемый все не просто списал или перекопировал. Универсальных способов решения этой проблемы пока не найдено. Отсюда радикальные предложения вообще отказаться от контрольных форм, ориентироваться лишь на расплывчатые «компетенции» в виде коммуникативных навыков, умения работать в команде и прочее.

Другая крайность цифровизации - это чрезмерная визуализация. Ее возможности поистине безграничны. Современный студент может просмотреть 
любой фильм на историческую тематику, где ему все покажут и расскажут и в цвете, и в движении. Причем покажет не кто-нибудь, пусть даже квалифицированный преподаватель, а мастера своего дела, профессионалы кинематографисты, документалисты, журналисты и комментаторы. Иногда преподаватели идут по пути наименьшего сопротивления и превращают занятия в своего рода «шоу». Хотят того, чтобы студентам было «весело» и «интересно». Вместо скучной лекции - занимательный фильм, вместо дат и перечислений исторических событий - видеофильм. Такие преподаватели часто пользуются популярностью у студентов, но проблема в том, что, по существу, они просто-напросто не ведут свой предмет и не формируют у студентов навыков сложного умственного труда. Нельзя превращать лекцию в шоу, а преподавателя в киномеханика, который включает и выключает интерактивную доску.

Подобным обучением у студента закрепляется так называемое «клиповое мышление» (сам термин появился ещё в середине 90-х годов), означающее особенность воспринимать мир через короткие яркие образы и послания видеоклипов и теленовостей. Мир в этом случае воспринимается не целостно, а маленькими блоками не связанных между собой событий, сменяющих друг друга без логической связи. Он превращается в калейдоскоп разрозненных фактов и осколков информации. В результате слушатель, не имея возможности осмыслить какую-либо тему, привыкает к постоянной смене сообщений и требует новых. Любая учеба должна быть связана с усилием, затратой физических и душевных сил, более того, к таким трудовым усилиям обучаемого надо принуждать, а не устраивать вечный праздник и «общество спектакля».

В преподавательской среде сложилось мнение, что цифровые технологии облегчили жизнь студентов, но усложнили ее для преподавателей. Для них переход от очного формата занятий к дистанционно-образовательному оказался весьма трудо-затратным. Каждая лекция должна быть подготовлена в электронном виде, и, под видом избавления преподавателей от рутинной работы вводится также автоматизированная проверка тестовых заданий, при которой проводить срез знаний с автоматическим выставлением оценки в электронный журнал должен преподаватель. Преподаватель должен стать наставником, направляющим и ориентирующим студентов в цифровом 
образовательном пространстве». Есть опасения, что в результате дистанционного обучения произойдёт сокращение преподавателей и отток опытных педагогов - именно тех, кто не желает отказываться от традиционной педагогики.

Возможно и увеличение разрыва между «элитарными» и «отстающими» учебными учреждениями, вплоть до возникновения вузов, выполняющих преимущественную роль «институтов призрения», «камер хранения для молодых недорослей». Государство будет постепенно выходить из образовательной сферы с сохранением лишь двух функций: удержания «базового уровня» (в логике социальной безопасности) и поддержки ограниченного числа «точек прорыва». Может, на «суррогат» можно переложить тот объем занятий, который не требует серьезного обсуждения, зато высвободить время для общения лицом к лицу.

Отсюда вывод, что будущее за смешанным форматом обучения, думается, наибольшая ставка должна делаться на сочетание онлайн-обучения и физического присутствия. С одной стороны, студент чувствует себя более комфортно, слушая лекции онлайн, куда можно выводить базовые вещи. Но образование - это не просто передача знаний, это дискуссия, обсуждение различных концепций, применение знаний к определенным концепциям. Практика показывает, что традиционная система обучения пока совершенно не проигрывает электронной системе, а наоборот, совершенствует умственные способности через речевое развитие на семинарах и концентрацию внимания на лекционных занятиях. 
DOI

УДК 37.015.31

Щербинина Ольга Сергеевна, старший преподаватель, Международный институт компьютерных технологий

\title{
ПЕДАГОГИЧЕСКОЕ ОБЩЕНИЕ В УСЛОВИЯХ ЦИФРОВИЗАЦИИ
}

\section{PEDAGOGICAL COMMUNICATION IN THE CONTEXT OF DIGITALIZATION}

\begin{abstract}
Аннотация: В статье отмечена актуальность использования цифровых технологий в образовательном процессе, описаны основные проблемы, вызванные переходом на новый формат дистанционного взаимодействия преподавателей и студентов, а так же особенности педагогического общения в новых условиях электронной среды.

Abstract: The article highlights the relevance of the use of digital technologies in the educational process, describes the main problems caused by the transition to a new format of remote interaction between teachers and students, as well as the features of pedagogical communication in the new conditions of the electronic environment.
\end{abstract}

Ключевые слова: цифровые технологии, дистанционное образование, педагогическое общение

Key words: digital technologies, distance education, pedagogical communication

Современный мир находится в постоянном движении. Динамика изменений в последнее время иногда пугает своими скоростями. Появляются новые технологии, которые проникают в различные сферы жизни человека. Уже с младенческого возраста дети смотрят мультики в мамином телефоне или папином планшете. Книги перестали быть единственным источником знаний. Библиотеки посещают лишь представители старшего поколения, потому что привыкли к бумажным носителям информации. А музыку они предпочитают слушать в фонотеках на виниловых пластинках. И это происходит не только по привычке, а иногда из-за отсутствия навыков работы в новых условиях цифровизации, которая становится новым трендом Российской действительности.

(ㅇ Щербинина О.С., 2021 
Ведь книга сейчас становится не просто электронной, она предоставляет целый спектр интерактивных и мультимедийных ресурсов. Музыка и фильмы давно оцифрованы и, пусть не всегда законно, могут быть найдены в бескрайней сети Интернет. Что же говорить о молодом поколении, у которого телефон стал практически продолжением руки и, порой на свидании, парень и девушка смотрят не в глаза друг другу, а в светящийся экран своего гаджета.

Цифровизация - это процесс вытеснения всего аналогового, охватывающий всё больше отраслей жизнедеятельности человека: технологии, экономику, культуру.

Проникли новые технологии и в систему образования. Данные инновации широко поддерживаются общественностью и государством. Благодаря цифровым технологиям появляются новые инструменты создания учебных материалов, а также способы доставки информации и знаний студентам.

Многие преподаватели с большим успехом используют цифровые технологии на своих занятиях, например, всем известные электронные презентации, электронные таблицы, текстовые редакторы, и многие другие распространенные офисные приложения. В настоящее время стремительно прогрессируют инструменты поиска и хранения информации, коммуникаторы, социальные сети.

Весной 2020 г. в условиях потрясшей весь мир пандемии COVID-19 профессиональная деятельность преподавателей вузов целиком и полностью была перенесена в принципиально новые условия дистанционного взаимодействия со студентами, причем даже по очной форме обучения. Однако эти вынужденные меры показали, насколько отечественная система образования ещё не готова к дистанционному обучению. А ведь именно к такому формату обучения плавно переходит образование во всем мире. О цифровизации образования сейчас говорят очень много, прогнозируя онлайнобразованию скорую победу над классическим университетским обучением.

Никто не станет спорить, что цифровые технологии открывают неограниченные возможности для доступа к цифровым инструментам, материалам и сервисам. Благодаря им все участники образовательного процесса получают беспрецедентный ранее контроль над своим информационным пространством и его совместным использованием. Однако педагогическое общение и взаимодействие между участниками учебного процесса, или 
педагогическая коммуникация, как в традиционной, так и электронной средах обучения составляют суть учебного процесса [3, С. 97].

«В психолого-педагогической литературе способность организовать взаимодействие с детьми часто называют коммуникативными способностями учителя. Порой, правильно найденная интонация, движение или выражение лица может помочь начинающему учителю наладить контакт с аудиторией. Взаимодействие обучающего и обучающегося является важным фактором успешности учебно-воспитательного процесса. Именно через общение в педагогическом процессе складывается та система взаимоотношений, которая приведет к эффективному воспитанию и обучению» [4, С. 128].

В процессе педагогической деятельности общение является средством решения учебных задач, социально-психологическим обеспечением воспитательного процесса, а также способом организации взаимоотношения субъектов педагогической деятельности, которые помогают обеспечить успешность обучения и воспитания [1, С. 12].

Все средства, способы и методы, с помощью которых педагог реализует свою педагогическую деятельность можно назвать стилем педагогического общения. Именно он подчас играет самую важную роль в процессе формирования межличностных отношений учащихся и влияет на результаты их обучения.

В условиях электронного обучения перед преподавателями так же стоит ряд задач:

- необходимо установить межличностные контакты между участниками процесса обучения;

- научиться строить общение через технические средства;

- сформировать эффективно работающие малые учебные группы;

- повысить мотивацию к обучению;

- создать благоприятный психологический климат при проведении обучения;

- соблюсти нормы и правила сетевого этикета и нормы педагогической этики.

Существуют определенные особенности педагогической коммуникации в электронной среде, качественно отличающие этот вид коммуникации от взаимодействия в традиционной образовательной среде. 
Дистанционное обучение - это процесс получения знаний, при котором преподаватель и студент физически не находятся в одном месте. При этом обучение осуществляется удаленно через Интернет с помощью видеозвонков, онлайн-курсов или мобильных приложений. То есть преподаватель не может контролировать эмоции или настроение студентов, чтобы подобрать нужный в данный момент ключик к каждому обучающемуся. В учебном классе преподаватель чувствует понимание аудитории материала по многим признакам и может скорректировать способ подачи информации. В режиме онлайн-лекции подача материала более формализована, сухая, потому что нет тесной связи с учениками.

В процессе электронного взаимодействия педагоги часто отмечают использование студентами языка мессенджеров, отличительными признаками которого являются письменное произношение, запечатленная разговорность, спонтанность, укорачивание фраз. Из-за заниженных требований к этикету страдает уровень вежливости и уважения к собеседнику (имя-обращение, написанное с маленькой буквы, разговорный стиль в письме студента к преподавателю). Это в итоге приводит к невозможности эффективно формировать коммуникативную компетенцию в целом. В дистанционном обучении в целом наблюдается тенденция к появлению новых элементов культуры общения или, если быть точнее, наблюдается игнорирование традиционных элементов культуры.

Кроме этого, в режиме онлайн-лекций часто происходит обезличивание студентов и самого преподавателя. Когда преподаватель смотрит на ученика, он видит личность со своими достоинствами и недостатками, проблемами и жизненной ситуацией, особенностями усвоения информации. Все это позволяет подходить к каждому индивидуально. В силу нежелания или технических проблем, в процессе дистанционного общения студенты, а порой и преподаватель, не используют веб-камеры, что затрудняет идентификацию личности. Вместо видеоизображения человека или его портрета на экране часто присутствуют картины природы, животные или другие элементы графики, не позволяющие увидеть истинное лицо студента или преподавателя. Потенциальная анонимность - значительное преимущество электронных коммуникаций, но она неприемлема в процессе обучения. 
При отсутствии социального взаимодействия студентов педагогу сложнее создать благоприятный психологический климат в коллективе. Многие студенты чувствуют себя изолированно без привычного общения со сверстниками, без шума в аудитории, без поддержки соседа по парте. Это может негативно повлиять на мотивацию и успеваемость. Поэтому преподаватель должен создать чувство общности в онлайн-среде. Постараться обращаться к студентам по имени, сохраняя дружелюбный тон, вызывать их на дискуссии по разбираемым проблемам, стараться создавать задания, требующие работы в малых группах. Следует всячески поддерживать учеников, рассказывая свои способы борьбы с текущей ситуацией.

Преподавателю необходимо иметь большое желание познать каждого студента в отдельности и быть готовым помочь ему в любой ситуации, не только в учебе. Нельзя забывать, что при моделировании взаимоотношений преподавателя и студента большое значение имеют их личностные качества. Старайтесь найти момент и подбодрить студента, поддержать или даже похвалить, если есть хоть какой-то прогресс [2, С. 83].

Дистанционное обучение сильно отличается от традиционного, что создает порой множество проблем. Но все они преодолимы, если перестать сопротивляться новому, изменить отношение к онлайн-формату и приобрести дополнительные технические навыки. Ведь основным преимуществом дистанционного образования является его доступность. Занятия могут посещать люди с ограничениями по здоровью или находящиеся в другом географическом регионе. Тем более, что данное направление активно поддерживается на государственном уровне.

Однако кадры для цифровой экономики должны быть не просто добросовестными исполнителями, они должны быть новаторами, и не столько приспосабливаться к меняющемуся миру, сколько менять его.

Но стоит помнить, что индивидуальный стиль педагогического общения и правильно построенные взаимоотношения между обучающим и обучающимся могут сформироваться только «при высокой профессиональной подготовке, творческом подходе к работе, высоком авторитете преподавателя» [2, С. 80]. Положительные результаты будут достигнуты не только благодаря современному оборудованию и новым технологиям, но и благодаря настоящим 
энтузиастам своего дела, которые используют современные методы обучения, требовательно, но при этом с уважением относятся к своим воспитанникам.

\section{БИБЛИОГРАФИЧЕСКИЙ СПИСОК}

1. Кан-Калик В. А. Учителю о педагогическом общении. - Москва : Просвещение, 1987. - 190 с.

2. Клейман Ж. Л., Аариева Т. М., Трущенко И. Н. Стиль педагогического общения как составляющая педагогической деятельности // Педагогика и современность. - № 2 (22). - 2016. - С. 80-84.

3. Розина И. Н. Педагогическая коммуникация в электронной среде // Известия вузов. Северо-Кавказский регион. - Серия: Общественные науки. 2004. - № 2. URL: https://cyberleninka.ru/article/n/pedagogicheskayakommunikatsiya-v-elektronnoy-srede (дата обращения: 17.04.2021).

4. Щербинина O. С. Педагогическое общение как элемент индивидуального стиля педагогической деятельности // Психологический и педагогический подходы к образованию в цифровом обществе: сборник статей Международной научно-практической конференции (1 февраля 2021 г., г. Воронеж). - Уфа : Аэтерна, 2021. - С. 127-130. 
DOI

УДК 374

Комаров Андрей Викторович,

аспирант,

Воронежский государственный педагогический университет

\author{
ОПЫТ ДИСТАНЦИОННОГО ОБУЧЕНИЯ АКТЁРСКОМУ \\ МАСТЕРСТВУ ВО ВРЕМЯ КАРАНТИНА НА ПРИМЕРЕ \\ ОБЪЕДИНЕНИЯ ТЕАТР-СТУДИЯ «ГЛАГОЛЬ»
}

\title{
THE EXPERIENCE OF E-LEARNING OF ACTING SKILLS DURING GUARANTINE ON THE EXAMPLE OF THE THEATER-STUDIO «GLAGOL»
}

\begin{abstract}
Аннотация: Данная статья продолжает анализ дистанционной деятельности подросткового объединения «ГлаголЂ». В настоящее время можно наблюдать возросший интерес к сфере электронного обучения, особенно в период карантина. В статье описывается опыт использования социальных сетей Вконтакте, Zoom, Discord для организации онлайн репетиционного процесса, видео и фото хостингом Youtube, Instagram, Tik Tok для публикации отчетных материалов обучающимися в период с марта 2020 г. по январь 2021 г. Выявлен ряд проблем при экспериментальной онлайн-работе и разработаны эффективные рекомендации по их устранению.
\end{abstract}

Abstract: This article continues the analysis of distance learning in the teenage association "GLAGOL". Currently, there is an increased interest in the field of e-learning, especially during the quarantine period. The article describes the experience of using social networks Vkontakte, Zoom, Discord for organizing online educational process, video and photo hosting Youtube, Instagram, Tik Tok for publishing reporting materials by students in the period from March 2020 to January 2021. A number of problems were identified during the experimental online work and effective recommendations for their elimination were developed.

Ключевые слова: электронное обучение, объединение, саморазвитие, социальная сеть, этюд, театр, актёрское мастерство, подкаст, хостинг, карантин

Keywords: e-learning, association, self-development, social network, etude, theater, acting, podcast, hosting, quarantine

Согласно федеральному закону «Об образовании в Российской Федерации» от 29.12.2012 г. № 273-Ф3 (ред. от 30.04.2021 г.) под электронным 
обучением понимается организация образовательной деятельности с применением содержащейся в базах данных и используемой при реализации образовательных программ информации и обеспечивающих ее обработку информационных технологий, технических средств, а также информационнотелекоммуникационных сетей, обеспечивающих передачу по линиям связи указанной информации, взаимодействие обучающихся и педагогических работников [1].

Одним из видов деятельности объединения всегда была электронная работа со зрительской аудиторией. С момента основания коллектива была создана группа Вконтакте, где размещались все новости и видео-отчеты о нашей деятельности, проводились онлайн конкурсы и открытые онлайн-читки. Также развивался онлайн проект \#КультураВМассы, в рамках которого публиковались различные статьи, написанные студийцами, культурно-просветительские видеоряд подкастов, информация и наше мнение о новых выставках, спектаклях и культурной жизни г. Воронежа.

В марте 2020 г., когда был объявлен карантин, студия не остановила своей работы, а напротив, с помощью дистанционных образовательных технологий было налажено электронное обучение. Было решено сконцентрироваться на работе в социальных сетях, так как это близко духу времени и входит в круг интересов студийцев. Для проведения репетиций, тренингов, мастер-классов, онлайн квестов и игр были использованы онлайн платформы Zoom, Discord, Вконтакте, каждая из которых обладает своими преимуществами.

Zoom - одна из самых удобных программ для проведения онлайн видео репетиций, мастер-классов для 15-20 человек, единственный минус которой заключается в лимитированном времени, всего 40 минут. Благодаря устойчивому сигналу и простоте интерфейса эта программа может быть использована для проведения прямых эфиров.

Discrod - данная программа удобна для проведения считок, легко устанавливается даже на телефон, но проведение массовых видео репетиций практически невозможно. Однако, мы использовали ее для организации мастерклассов по работе с видеоредакторами, так как они длились по 2-3 часа.

После перехода на электронное обучение принято решение создать серию коротких и актуальных этюдов о трудностях жизни подростков в рамках новых реалий, \#Глагольдома. После ее успеха, согласно целям и задачам 
образовательной программы, были разработаны задания-рубрики для самостоятельной работы обучающихся, которые публиковались на различных интернет хостингах.

Идеальной площадкой для работы с этюдами оказался Tik Tok социальная сеть «поколения $\mathrm{Z}$ », в которой можно записывать короткие видео до трёх минут продолжительности. Здесь существует множество инструментов для монтажа любой сложности: маски, фильтры, эффекты, переходы и т.д. Её контентом являются вертикальные скетчи. Мы используем её как тренировочную базу перед работой над более масштабными проектами. Здесь публикуются экспериментальные рубрики: пародии на студийную жизнь, бэкстейджи, а также запускается и принимается участие в различных театральных челенджах и флешмобах.

Театр - это в первую очередь перевоплощение, смена сценического образа. Уже давно в мире популярно движение косплея, то есть костюмированной игры. В рубрике \#КосплейГлаголЬ обучающиеся сами выбирали себе образ известных героев мультфильмов и фильмов, работали над гримом и костюмами, а потом публиковали свои работы в Instagram, на наш взгляд, лучшей электронной платформе для публикации и обработки фотографий.

В рамках онлайн проекта \#КультураВМассы на сервере YouTube, как наиболее подходящим для размещения видео крупного размера без потери качества, был запущен проект постановки моно-спектаклей по мотивам сказок народов мира - \#ЧитайГлаголЬ. В период с апреля по август 2020 г. было опубликовано более 80 различных выпусков. Здесь нашел своё применение весь творческий потенциал коллектива. Среди выпусков были: театр теней, театр кукол, мюзиклы, пантомимы, мультфильмы, 2D-проекции, авторские сказки и многое другое. В данную работу оказались вовлечены не только студийцы, их родители и родственники, но и друзья. Со временем даже появилась новая ветвь \#ЧитайСГлаголЊом. Наши друзья и подписчики с разных концов страны записывали сказки вместе с нами. Помимо сказок, запущена рубрика \#ТеатрВнеТеатра, в рамках которой было снято порядка 15 клипов под бардовские песни и 4 короткометражных фильма [2].

Однако, как бы эти хостинги не были удобны, универсальным, на наш взгляд, является социальная сеть Вконтакте. Здесь была опубликована серия 
комиксов \#ГлагольныеХроники, которая в сатирической форме рассказывает об истории основания и развития коллектива. Для ее выпуска была проведена серия онлайн-интервью с выпускниками студии и были просмотрены и обработаны более 12000 фотографий. Кроме того, активно проводятся онлайн конкурсы и опросы, например \#ГлухойГлаголь зрителям предлагается угадать слово, которое пантомимой показано на видео. С сентября 2020 г. была запущена новая рубрика \#СлушайГлаголЂ, в рамках которой ежедневно публикуются стихотворения не только классических, но и современных авторов в исполнении актеров студии. Более того, Вконтакте - очень удобная площадка для онлайнтрансляций концертов на платформе Zoom. Первый был посвящен 75-летию Победы. Осенью, во время праздничных мероприятий, посвящённых Дню Города Воронежа, обучающиеся успешно осуществили вещание с 5 различных точек города, рассказывая о своем авторском квесте по культурно-исторической части города. Кроме того, летом 2020 г. коллектив принимал активное участие в создании детского летнего онлайн лагеря [3].

Вопреки тому, что всё это близко студийцам были выделены следующие актуальные проблемы:

- снижение мотивации, так как все идеи очень быстро надоедают;

- низкий уровень контроля над подготовкой работ;

- отсутствие живого контакта со зрителем, сценой как таковой;

- неумение работать с электронными устройствами (камера, фотоаппарат, программы);

- со временем наблюдается снижение уровня оперативности;

- потеря театральной направленности.

Был разработан комплекс мер, направленных на повышение эффективности электронного образования:

- постоянная смена видов деятельности и их направленности, апробирование новых жанров;

- проведение регулярных консультаций в мессенджерах, напоминание о сроках выполнения заданий.

- проведение ежедневных опросов студийцев и аудитории;

- проведение серии мастер-классов по технической подготовке материалов на всех устройствах: компьютер, планшет, телефон. 
- организация 10 минуток каждые два дня, на которых проводится текущий контроль.

Подводя итог, можно утверждать, электронное обучение способствовало непрерывности образовательного процесса в период карантина, а также помогло предотвратить распространение короновирусной инфекции. Более того, это один из шансов для студийцев проявить свои таланты во многих сферах творчества и искусства, привлечь новую зрительскую аудиторию. Оно влияет на актуализацию образовательного процесса, реализацию и развитие творческих способностей, ответственности за свои дела и поступки, развитие умений общаться, работать в команде, развитие способностей к самоопределению, профориентированию, саморефлексии. Более того, у студийцев развиваются способности к самоконтролю, самокоррекции, саморегуляции. Несмотря на потерю живого общения со зрителем в период с марта 2020 г. по январь 2021 г., предпринимаются попытки компенсировать это разнообразным материалом.

\section{БИБЛИОГРАФИЧЕСКИЙ СПИСОК}

1. Об образовании в Российской Федерации: Федеральный закон Российской Федерации от 29.12.2012 г. № 273-Ф3 (ред. от 07.03.2018 г.) // Собрание законодательства Российской Федерации. - 2012. - № 53. - С. 7598.

2. Комаров А. В., Востроилова Е. В. Организация досуговой деятельности воспитанников на базе объединения театральная студия «Отражение» // Человек и общество: история и современность. Межвузовский сборник научных трудов / науч. ред. М. В. Шакурова. - Воронеж: ВГПУ, 2017. - 184 с.

3. Комаров А. В. Театр-студия «Созвездие» к вопросу о его образовательной деятельности // Образовательная деятельность в контексте практик социального партнерства: материалы открытой региональной конференции, 12-13 апреля 2018 г. - Воронеж: ВГПУ, 2018. - 318 с. 


\section{DOI}

УДК 004:316.776

Квасов Олег Николаевич, доктор исторических наук, заведующий кафедрой социально-гуманитарных наук, Воронежский государственный лесотехнический университет имени Г.Ф. Морозова

\section{ИНСТИТУЦИОНАЛИЗАЦИЯ КИБЕРПРОСТРАНСТВА}

\section{INSTITUTIONALIZATION OF CYBERSPACE}

Аннотация: В работе рассматривается формирование цифрового пространства как социального института. Анализируются основные признаки институализации киберпространства, такие как регулятивная функция, набор ролей, ритуализированное взаимодействие, совокупность регламентирующих учреждений и система общественного контроля данного института. Автор делает ряд выводов и прогнозов относительно формирования института киберпространства.

Annotation: The work examines the formation of digital space as a social institution. The main features of the institutionalization of cyberspace are analyzed, such as the regulatory function, a set of roles, ritualized interaction, a set of regulatory institutions and the system of public control of this institution. The author makes a number of conclusions and forecasts regarding the formation of the institution of cyberspace.

Ключевые слова: киберпространство, социальный институт, институционализация, сетевое пространство, информационное пространство.

Key words: cyberspace, social institution, institutionalization, network space, information space.

Еще каких-то десять лет назад никто не мог представить себе тектонический объем изменений, в которых окажется современное человечество. Ни футурологи, ни фантасты даже в самых смелых своих предсказаниях и творческих фантазиях не предполагали, что виртуальная реальность настолько обширно и глубоко войдет в нашу жизнь. Продвижение всевозможных продуктов компьютерных технологий воспринималось и осознавалось как естественное и позитивное в определенных сферах 
общественной жизни - экономике, кибернетике, коммуникации и прочее. И, в первую очередь, если не единственно, в роли инструментария, более совершенного, компактного, функционального. Перспектив проникновения цифровых коммуникаций, тем более в роли субъекта отношений, в личную жизнь, в общественные отношения, в политику, в образование и воспитание, не предполагалось. Обстоятельства эпидемии, вынужденный карантин и длительная изолированность стали важнейшим условием и фактором стремительного развития цифровых технологий, внедрения их в нашу общественную и личную сферы. Из обычного, хотя и «продвинутого» инструментария виртуальная цифровая сфера в одночасье превратилась в субъекта общественных отношений. Вероятно, человечество еще ни разу в своей истории не сталкивалось с таким «скоропостижным», глобальным и непрогнозируемым феноменом рождения. Поэтому столько неопределенностей - отсутствуют единый понятийный аппарат, этическая, аксиологическая, да и вообще, общественная легитимация этого виртуального мира. Процесс осознания, адаптации, «очеловечивания» цифрового пространства еще только начался и до его завершения далеко. Поэтому очень важно определить основные конструктивные и функциональные контуры нового общественного института.

Понятие «социальный институт» является одним из определяющих в социологии. Все известные социологи в той или иной мере касались вопросов институционализации общественной жизни. В трактовке сути этого понятия преимущественно фигурируют две точки зрения. Первая характеризует социальный институт как результат внедрения и навязывания управленческими структурами обществу определенных правил. Второй, считает появление социального института естественным и закономерным результатом оптимизации совместной деятельности людей. Различие в понимание сути явления, отражается и в выделение характеризующих признаков социального института. Исследователь жизни африканских аборигенов Б. Малиновский, на примере брачного обряда, выделял четыре ключевых элемента: регулятивная сущность института, ролевой набор, ритуализированное взаимодействие и материальные атрибуты. В современном развитом институциональном обществе ключевых элементов выделяют несколько больше. К традиционным относят систему ролей; совокупность учреждений, регламентирующих деятельность института; систему норм и санкций данного института; набор 
традиций, обычаев и ритуалов поведения в рамках института. При этом добавляются и два новых - ресурсы, определяющие общественную значимость института, и выраженную роль и функциональность института относительно других институциональных образований.

Социальные институты (семья, политика, экономика и пр.) характеризует, в первую очередь, историчность и объективность, но не менее важными свойствами, без которых функциональность институтов отсутствовала бы, являются их принудительный характер организации и легитимизирующий статус. Активная актуализация этих характерных признаков наблюдается сейчас в становление института кибернетического пространства. Важно объективно понимать как проявляющиеся тенденции, так и факторы, влияющие на противоречивое развитие этого института.

Во-первых, как было уже сказано, неопределенность касается дефиниций, границ и функциональности новорожденного института. Под цифровым обществом подразумевается одновременно и пространство («киберпространство», «информационное пространство», «медиапространство»), и функция. Таким образом, цифровой институт включает в себя весь континуум компьютерных, сетевых технологий и интернет-ресурсов, которые активно реализуют, насыщают и формируют не только информационные функции, но и коммуникативные, тем самым безгранично расширяя ноосферное пространство человека и общества. Можно заключить, что «цифровая медиасреда имеет высокий интегрирующий и синергетический эффект по отношению не только к технологическому, но и к социокультурному уровню развития современного общества» [2, С. 335]. Очевидно, что эти возможности цифровой среды помимо того, что стимулировали становление новых научных направлений, расширили научные перспективы и междисциплинарную интеграцию, а также дали возможность знаниям стать общенародным, общественным достоянием, ускорили процесс внедрения знаний в общественную среду, они одновременно с этим, и, как ни странно, усилили ресурсы, потенциал и возможности контроля государственного сектора за социальным взаимодействием и бытием человека. Огромные масштаб и глубина этого контроля никакому тоталитарному государству и не снились! И эти возможности государственными и административными органами только начинают осознаваться и осваиваться. Чем обернутся эти государственные возможности для общества можно только 
предполагать, но очевидно, что сфера личного, интимного пространства будет всё более сокращаться.

Во-вторых, что касается совокупности учреждений, регламентирующих деятельность института. Помимо четырех ключевых организаций технически формирующих мировую сеть (Общество Интернета (Internet Society), Инженерный Совет Интернета (Internet Engineering Task Force), Консорциум World Wide Web (W3C), Корпорация по управлению доменными именами и IPадресами (Internet Corporation for Assigned Names and Numbers)), существуют национальные центры и множество местных провайдеров. Техническими ресурсами Интернета пользуется огромное количество разнообразных пользователей как корпоративных, так и персональных. Те структуры, которые создают потребительский товар на основе технических возможностей интернета по природе своей руководствуются законами информационного мейнстрима и хайпа. Что противоречит позитивной оценке киберпространства и выталкивает его в маргинальный статус в глазах очень многих людей. По всей видимости, эта ситуацию получит скорейшее разрешение либо в пользу появления какой-то системы контроля, что уже на протяжение нескольких лет происходит, либо само киберпространство согласиться с маргинальным своим статусом, что чревато ограничением доходов, возможностей и пр., и что маловероятно. Вполне вероятна, сегментация киберпространства по функциональным сферам для обучения, развлечения, контроля и управления, и пр.

В-третьих, система норм и санкций данного института. Мы находимся на стадии формирования нормативной системы цифрового пространства, но при этом наблюдаем многочисленные факты, когда кибердеятельность и киберпоступки вступают в противоречие с уже имеющимися нормативными системами [1, 3]. Это касается конфликтов с нарушением авторских прав, культурных и этических норм, социальных традиций, киберпреступностью, вопросами национальной безопасности и пр. Свобода как одно из важнейших положительных качеств и достоинств цифрового пространства, стремительно превращается в его отрицательные следствия, умножая хамство, невежество и преступления, и прямо-таки, заставляя государство формализировать запреты и санкции, навязывать провайдерам и платформам ограничительные правила и нормы. По всей видимости, тенденцией в кибернетическом пространстве станет всё более выраженное ограничение категории Свобода, вплоть до трансформации её в аморфное и относительное понятие Возможность. 
Четвертая важная характеристика любого института - это своеобразный набор традиций, обычаев и ритуалов поведения. Вся система социального контроля в сети только на стадии формирования. В итоге мы наблюдаем одновременно как удивительные примеры активного роста межкультурной, социальной, групповой коммуникации, так и примеры прямо противоположного характера - разжигание конфликтов, массовое третирование и оболвание, аморальность. Как совершенно правильно указывают известные исследователи проблемы: «Цифровизация сопровождает любой акт коммуникации, участвуя в изменении и воспроизводстве сложившихся социальных связей» [4]. И от нас зависит как, в какой форме и содержание будет выстраиваться повседневная среда жизни в информационном пространстве. Необходимо признать, человечество получило очередной шанс сделать мир лучше, построить его с ноля без горя, зависти и злобы. И по всей видимости, в очередной раз человечество не оправдало надежд Создателя наша информационная среда далека от идеальной, более того даже от традиционной системы ценностей.

Пятым показателем института является наличие уникальных ресурсов, определяющие общественную значимость. Сейчас мы наблюдаем как происходит формирование и распределение информационных ресурсов планеты. Несмотря на информационную безграничность, относительную доступность медиапространства и стремительное развитие технических возможностей, «сегодня чуть более $40 \%$ от общей численности населения мира - примерно 3,2 млрд человек - еще не подключены к интернету. Более миллиарда «неподключенных» живут в Южной Азии (31\% от общего числа). На страны Африки приходится $27 \%$, то есть 870 млн. человек по всему континенту» [5]. Такая же, ситуация с дифференциацией пользователей касается гендерных, возрастных, профессиональных и прочих критериев. Таким образом, можно сказать, что развитие интернета не ликвидировало и не отменило социальную дифференциацию и стратификацию, а еще более её конкретизировало и углубило. Более того, есть все основания выделить категорию информационное неравенство в статус базисных и напрямую связать его с экономическим и культурным неравенством.

Шестым маркером институциональности является выраженная роль и функциональность института относительно других системных образований. Большая значимость в современном мире информации априори порождает высокий статус цифрового института, необходимость взаимодействия и 
согласования межинститутских связей. При этом, далеко не очевидным являются последствия этого взаимодействия для разных институтов. И если такие базисные институты как политика и экономика рассматривают киберпространство как новый инструмент своего функционала, то образование, религия и семья не могут определиться в своем отношении.

Традиционное образование в лице киберпространства получило сильнейшего информационного и знаниевого конкурента. Отрицать и отказывать в огромных обучающих возможностях мультимедийным комплексам не объективно. Более того есть все основания говорить о том, что в сети разрыв между наукой и образованием можно минимизировать, если вообще не ликвидировать. Однако в воспитательной и социализирующей функциях цифровое пространство пока уступает структурам классической системы образования. Взаимосвязи обучения, воспитания и социализации, что и формирует классический институт образования и создает продукт в виде «гармонично развитой личности», в киберпространстве нет и, по всей видимости, не будет. Однако с развитием и проникновением киберпространства в общественную жизнь всё может кардинально измениться, но это будет уже напрямую связано с процессом «расчеловечивания».

Ортодоксальная церковь до сих пор надеялась на отсутствие конкурентных противоречий с киберпространством, однако и в свой инструментарий цифровое пространство не включало. Но перспектива появления Цифрового Бога становится всё более реальной, что вызовет либо начало взаимодействия этих двух институтов, либо их антагонизм.

Серьезно и, по всей видимости необратимо, от цифрового пространства пострадал институт семьи. Практически все функции семьи, которые на протяжение всего процесса социогенеза и антропогенеза определяли значимость этого института могут выполняться, дублироваться или подменяться возможностями и суррогатами киберпространства (экономическая, эмоциональная, досуговая, сексуальная). Функция первичной социализации, как уже было сказано выше, с развитием, ростом и совершенствованием цифрового пространства вполне вероятно будет также конкурентно выполняться в медиапространстве. Важнейший аргумент и фундамент института семьи в виде репродуктивной функции в современных условиях воспринимается уже далеко не однозначно и подчас не как общественная ценность (движение чайлдфри). В конечно итоге, необходимо признать фатальные последствия влияния медиапространства на институт 
традиционной семьи, а что собой будет представлять киберсемья, пока еще не ясно.

Таким образом, краткий, тезисный анализ позволяет заключить, что появление цифрового пространства объективный факт, который влияет на трансформацию всей институциональной структуры общества, но его функциональная роль и место еще далеко не конкретизированы.

\section{БИБЛИОГРАФИЧЕСКИЙ СПИСОК}

1. Доктрина информационной безопасности РФ от 05.12.2016 г. http://www.scrf.gov.ru/documents/6/135.html (дата обращения: 21.02.2021).

2. Марьина Е. Ю. Цифровое пространство: противоречия становления и развития // Young Scientist. - 2016. - № 9 (36). - С. 335-339.

3. Указ Президента РФ от 09.05.2017 г. № 203 «О Стратегии развития информационного общества в РФ на 2017-2030 гг.» // Собрание законодательства РФ. - М., 2017. - № 20. - Ст. 2901.

4. Пфаненштиль И. А., Панарин В. И. Цифровое образовательное пространство и проблема «расчеловечивания» // Профессиональное образование в современном мире. - 2020. - Т. 10. - № 2. - С. 3658.

5. https://www.web-canape.ru/business/internet-2020-globalnaya-statistikai-trend (дата обращения: 21.02.2021). 


\section{СВЕДЕНИЯ ОБ АВТОРАХ}

Алесин Игорь Иванович - кандидат философских наук, преподавательорганизатор основ безопасности жизнедеятельности, МБОУ СОШ № 14 г. Воронежа, ialesin@ mail.ru.

Белянская Татьяна Эдуардовна - преподаватель кафедры социальногуманитарных наук, Воронежский государственный лесотехнический университет имени Г.Ф. Морозова, tabel71@ mail.ru.

Гришин Андрей Александрович - преподаватель кафедры социальногуманитарных наук, Воронежский государственный лесотехнический университет имени Г.Ф. Морозова, iamaphilosopher@yandex.ru.

Квасов Олег Николаевич - доктор исторических наук, доцент, заведующий кафедрой социально-гуманитарных наук, Воронежский государственный лесотехнический университет им. Г.Ф. Морозова, kvasovoleg@yandex.ru.

Комаров Андрей Викторович - аспирант кафедры социальной педагогики, Воронежский государственный педагогический университет, педагог дополнительного образования МБУДО Дом детского творчества, kamarik_teatr@mail.ru.

Моисеева Мария Петровна - магистрант психолого-педагогического факультета, Воронежский государственный педагогический университет, moiseeva.mp@bk.ru.

Новикова Зоя Николаевна - старший преподаватель кафедры социальногуманитарных наук, Воронежский государственный лесотехнический университет имени Г.Ф. Морозова, novikova.zoja@yandex.ru.

Петряева Татьяна Андреевна - преподаватель кафедры социальногуманитарных наук, Воронежский государственный лесотехнический университет имени Г.Ф. Морозова, tanyapetryaeva@yandex.ru.

Попова Марина Анатольевна - доцент кафедры естественно-научных и гуманитарных дисциплин, кандидат политических наук, доцент, Международный институт компьютерных технологий, vuz@iict.ru.

Пушкин Александр Сергеевич - студент физико-математического факультета, Воронежский государственный педагогический университет, pushkinsasha.rus@yandex.ru. 
Пушкина Тамара Федоровна - кандидат педагогических наук, доцент, Воронежский государственный педагогический университет, pushkina.dom@yandex.ru.

Семенова Елена Викторовна - старший преподаватель кафедры социальногуманитарных наук, Воронежский государственный лесотехнический университет имени Г.Ф. Морозова, elenaviktor2014@mail.ru.

Трегубова Анна Сергеевна - студентка лесного факультета, Воронежский государственный лесотехнический университет имени Г.Ф. Морозова, tregub0waa@yandex.ru.

Сухоруких Алексей Викторович - доктор философских наук, доцент кафедры социально-гуманитарных наук, Воронежский государственный лесотехнический университет имени Г.Ф. Морозова, sukhorukikh.al@ yandex.ru. Чаплыгин Андрей Владимирович - доцент кафедры естественно-научных и гуманитарных дисциплин, кандидат физико-математических наук, доцент, Международный институт компьютерных технологий, vuz@iict.ru.

Чучупал Вячеслав Васильевич - старший преподаватель кафедры социальногуманитарных наук, Воронежский государственный лесотехнический университет имени Г. Ф. Морозова, erbium@ yandex.ru.

Щербинина Ольга Сергеевна - старший преподаватель, Международный институт компьютерных технологий, olyly1979@ mail.ru. 
Научное издание

\section{ЦИФРОВОЕ ОБЩЕСТВО: \\ ПРОБЛЕМЫ И ПЕРСПЕКТИВЫ РАЗВИТИЯ}

Сборник научных трудов по материалам

Всероссийской научно-практической конференции

22 апреля 2021 г.

Под редакцией доктора исторических наук, доцента О.Н. Квасова

Материалы публикуются в авторской редакции

Подписано в печать Формат 60×90/16.

Усл. печ. л. 6,1. Уч.-изд. л. 6,2. Тираж 50 экз. Заказ

ФГБОУ ВО «Воронежский государственный лесотехнический университет имени Г.Ф. Морозова»

ФГБОУ ВО «ВГЛТУ». 394087, г. Воронеж, ул. Тимирязева, 8 УОП ФГБОУ ВО «ВГЛТУ». 394087, г. Воронеж, ул. Докучаева, 10 